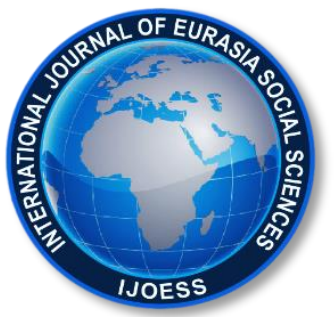

International Journal of Eurasia Social Sciences

Vol: 11, Issue: 40, pp. (458-492).

Article Type: Research Article

Received: 20.12 .2019

Accepted: 13.05 .2020

Published: 07.06.2020

\title{
THE EFFECTS OF THE MENSTRUATION PERIOD ON THE PERCEPTION OF AGING VIA IMITATION OF MENOPAUSE
}

\author{
Fahri ÖZSUNGUR \\ Dr., Adana Trade Registry Office, Turkey, ticaretsicili@gmail.com \\ ORCID: 0000-0001-6567-766X
}

\begin{abstract}
It was aimed to determine the effects of menopause and menstruation on women's aging perception in this study. This study was conducted in August 2019 with 66 female participants (living in the province of Adana in Turkey; selected from 79 females). In this study, it was found that the perception of aging emerged as a result of the participants' comparison and internalization of the information obtained from the elderly people and themselves who exposed to the symptoms of aging. The relationship between menstruation and the perception of aging was weak, while menopause was associated with the perception of aging. According to the participants who think that menopause and menstruation are related to aging, aging is a decline process. Women imitate the people around them regarding menopause and aging perception. The ability of menopause to imitate the effect of menstruation on aging perception was determined. It was revealed that menopause had the ability to imitate the perception of aging in women through cognitive learning. The ability to imitate was determined by the effect of menstruation symptoms on the perception of aging. The limitation of the sample to the province of Adana limited the generalizability of the study. This is the first study that reveals the effects of the menstruation period on the perception of aging and imitation of menopause. Theoretical background, discussion, managerial implications, limitations and recommendations for future studies are discussed.
\end{abstract}

Keywords: Menstruation period, menopause, ,imitation of aging, gerontology, aging 


\section{INTRODUCTION}

Due to their biological characteristics, women experience some important changes since puberty. Two of these changes are menstruation and menopause. Menstruation is a hemorrhagic biological event that provides reproductive cycles of women, varying between 3-7 days, starting from 11 to 14 years of age due to biological growth and continuing until menopause (Dye, Warner \& Bancroft, 1995; Bancroft, 1995). The quality of daily life is negatively affected due to the blood evacuation from the vagina and psychological effects. Menstrual cramps (dysmenorrhea) are one of the most common syndromes in menstruation. These pains can occur due to cervical stenosis, psychological disorders, and endometriosis (Zimmerman \& Parlee, 1973; Sanders et al., 1983).

Abdominal or pelvic cramping pain, headache, premenstrual syndrome, food or sweet cravings, bloating, lower back pain, mood swings, sore breasts, fatigue, premenstrual dysphoric disorder (tension, irritability, depression symptoms) are the clinically determined symptoms of menstruation (Metcalf et al., 1991). During menopause, the amount of follicles in the ovaries decreases and as a result, estrogen production decreases. Over time, estrogen production is discontinued and the ovaries become smaller. As a result, the menstrual cycle is interrupted and reproductive ability is lost. These events occur in a process (Reiber, 2010; Treloar, 1981).

Menopause has three basic periods as premenopause, menopause and postmenopause. Premenopause is a period in which menstrual irregularities occur and follicle activity in the ovaries decreases. Menstrual bleeding stops at the stage of transition to menopause. After this process, amenorrhea emerges for at least one year. All three processes have significant biological, physical and psychological effects (Nelson et al., 2008; Harlow et al., 2003; Koff, Rierdan \& Stubbs, 1990).

Research has shown that a decrease in estrogen levels leads to mood changes. Vasomotor symptoms caused by dilation of the vessels in the face and neck cause hot flashes and night sweats. Atrophic and psychological changes may occur during this process. These psychological factors can cause women to be adversely affected by the information they gained from each other (Porter et al., 1996; Taskin et al., 1998; Kitell, Mansfield \& Voda, 1998). The literature has focused on the psychological consequences of menopause and menstruation, but the perceptual outcomes of these results have been ignored. Comparing information about menopause from women of different age groups and the Internet with changes in their own body may reveal significant problems(Morse \& Dennerstein, 1988). Besides, it is another phenomenon whether menopause resulting from increasing age creates a perception of aging.

The perception of aging is an important issue that affects an individual's psychological state related to old age (Levy et al., 2002; Levy \& Myers, 2004). Perception is a factor that controls the individual's behavior and is influenced by the physical and social environment (Levy, Slade \& Kasl, 2002; Hooker et al., 2019). Perceptions that can be controlled by effective management have a significant impact on the aging process management (Srivarathan, Jensen \& Kristiansen, 2019; Smith \& Bryant, 2019). Studies show that perception is an important 
factor in managing the aging process (Condello et al., 2019; Parish et al., 2019; Gurera \& Isaacowitz, 2019). Cognitive aging is a theoretical approach that emerges in this context (Salthouse, 2019; Franceschi et al., 2019).

Cognitive aging involves the decline of functions such as memory, coding of information, inhibition, remembering, reasoning, attention, emotion control and creativity in the aging process of individuals under the influence of the social and physical environment (Clouston et al., 2019; Haines et al., 2019). As getting older, psychological, emotional and physical declines gradually increase their negative effects on individuals. After retirement, active participation in social life decreases and the individual is pushed to loneliness due to health problems (Komanduri et al., 2019; Karlsson, Thorvaldsson \& Johansson, 2019). Thus, the individual who starts to withdraw from life can ignore and neglect her/his psychological and pathological diseases (Sexton et al., 2019). These attitudes and behaviors cause an individual's decline in life functions. Cognitive functions are significantly affected by these declines (Russell, Jones \& Newhouse, 2019; Tucker-Drob, 2019; Roberts, 2019; Yu et al., 2019; Webb et al., 2019).

Alzheimer's and Parkinson's diseases, cognitive decline in the elderly occurs as a result of damage to the perceptual process (Lamar et al., 2020; Tenner, 2020; Ray \& Agarwal, 2020; Petkus et al., 2020). Cognitive impairment is caused by the misuse of drugs, depression, dementia, endocrine derangements (Jenraumjit et al., 2020). Declines prevents the use of cognitive abilities. Problems recalling stored information and coding errors make it difficult to remember. Psychological problems such as depression and anxiety may trigger this condition (Moeller et al., 2020). Therefore, events experienced by the individual throughout his life, health problems and social pressure are effective in this process.

Cognitive aging in women develops under factors such as gynecological diseases, child care, pregnancy, menstruation, menopause, discrimination, social pressure, exposure to harassment and rape (Sobhani et al., 2019; Prior, 2020). Pregnancy creates significant physical and emotional changes in women (Reicher, Yogev \& Maslovitz, 2020; Richardson, 2020; Michael et al., 2020). Women who develop a sense of ownership have a psychologically defensive personality (Goodwin et al., 2019). These changes may adversely affect the individual's social adaptation (McGannon et al., 2019). The social pressures that women are exposed to according to their social environment also negatively affect their psychology (Watson, 2019; Tilly \& Scott, 2016). The reasons such as early marriage, domestic violence, low muscle strength of women and lack of economic independence affect women's cognitive aging (Coveney et al., 2019; Meriwether, 2018; Abramovitz, 2017).

Menstruation is one of the factors that adversely affect the cognitive aging of women (Golub, 2017). Menstruation is bleeding and painfully period that occurs during adolescence (Koeske, 2017). In this period, women face many difficulties in their daily lives. Especially women who have to use pads due to bleeding experience significant difficulties in doing activities such as swimming and sport (Motro, Gabriel \& Ellis, 2019). On the other hand, women experience psychological irritability and anxiety during their menstruation period (Marván, M. L. \& Chrisler, 2018). Irregularities experienced during menstruation, excessive bleeding, pain, and 
burns in the genital area decrease the quality of life (Hosseini, 2018). All these effects can lead to the psychological exhaustion of women during the aging process (Ismail, Pedro \& Andipatin, 2016). In addition, health problems caused by gynecological diseases may prevent them from successfully managing this aging process (Cameron et al., 2019; Mobarak et al., 2019; Crimmins et al., 2019; Karim et al., 2019).

Menopause is the absence of menstruation bleeding in women for a year (Reid et al., 2020). This period is an important period in which women step into old age (Smail, Jassim \& Shakil, 2020). This condition is usually seen at 45 years of age and older (Muhleissen \& Herbst-Kralovetz, 2016). Hot flashes, sweating, weakness, forgetfulness, palpitations, anxiety, irritability, vaginal infections are the symptoms emerge in this period (Gambacciani et al., 2018). Women may experience some of the symptoms they experience during menstruation, similar to menopause (Meyvaci et al., 2020). Menopause, which affects the active participation of women in life, can cause a perception of aging (Levine et al., 2016). Research has shown that menopause perceptions of women may be related to aging. Menopause that occurs during entering the old age can reveal the perception of aging in the individual (Greer, 2018; Manson \& Kaunitz, 2016; Johnstone \& Cant, 2019). However, the relationship between the emergence of menopause before the aging period in general and the menstruation period has not been investigated in the literature.

Menstruation and menopause are two important issues affecting the quality of life and well-being of women (Skultans, 1970). These issues may cause women to encounter important psychological, physical and psychosocial consequences in their business and social lives. One of these results is the perception of aging. Perceptions of aging and successful aging due to the problems experienced by menstruation and menopause in the aging process are the current issues that need to be investigated (Martin, 1988; Parlee, 1976). In this study, the aging perception and successful aging of women who have to maintain daily life by being exposed to the physical and biological effects of menstruation and menopause were investigated.

\section{METHODOLOGY}

\section{The Aim of the Study}

This study aimed to determine the role of menopause in the effect of perceptions of menstruation on aging. Besides, the study aims to examine the menopause and menstruation periods that affect women's perception and affect women at a significant level. Considering the anatomical differences of women compared to men, investigating the perception of aging will make important contributions to the literature. In particular, the effects of menstruation and menopause periods on women in terms of certain characteristics have not been studied in the context of aging. This is the first qualitative study examining the relationship between aging perception and the menstruation and menopause periods. The findings of the study are thought to make significant contributions to family and consumer sciences, women studies, gynecology, social gerontology, social work, and aging studies. The mediating role of menopause in the perception of aging will make important contributions to understanding women's perceptions of aging. 
The target mass of our study is the women of 35-50 age range, which constitutes a transition process between menstruation and menopause. Because in this age range, women's perceptions of aging start to become clearer. Besides, menstruation periods begin to end and the transition to menopause begins. In this context, the research question has been formed as follows: "Is there a mediating role of menopause in the effect of menstruation on aging perceptions in women? ", "Does this mediating role reveal an imitation ability?"

\section{Sample}

Since the target group of the study is women and due to the difficulty of reaching this population, the selection of the universe and sample was narrowed. Therefore, the purposeful and random sampling method was preferred in the study (Byrne, 2001; Marshall, 1996; Koerber \& McMichael, 2008). Firstly, women working in a job in Adana province were selected and a sub-group of women working in official institutions was formed. Thus, it became easier to select the sample. The number of samples suggested in the literature varies between 5-25 (Marshall, 1996; Koerber \& McMichael, 2008). This study was conducted in August 2019 with 66 female participants (living in the province of Adana in Turkey; selected from 79 females; ages ranging between 35 to 48). However, 13 participants refused to participate in the research. The study was conducted in an official institution. The institution did not allow the name to be disclosed. Participants' consent for this research was obtained.

\section{The Method Used in the Data Collection Stage}

Qualitative research methodology and multiple case design were adopted in this study. A structured interview, data collection approach, and observation techniques were used (Gerring, 2004). The predetermined questions were asked to all participants in the same order (Gall, Barg \& Gall, 1996). Qualitative data were analyzed by an academician, who had not previously worked in this field to minimize the systematic error (Maxwell, 1996). Conceptualization, classification and component analysis were applied respectively in data analysis (Spradley, 1980). A total of eleven questions were asked to the participants (Appendix 1). These eleven questions were based on the information obtained from individuals' past experiences that aim to reveal the associations. After the questions were asked, individuals were asked to submit the medical reports of gynecological diseases diagnosed by a doctor. The reports were compared with the responses.

\section{Data Analysis}

In the analysis of qualitative data, MAXQDA and Voyant Tools programs, which include concept mapping techniques, were used. The analysis of the data was evaluated by two academicians who were not involved in the study field in order to minimize the risk of systematic errors. The evaluations were compared, the differences were analyzed and the common results were reported. The data were processed by the traditional method and analyzed. Data analysis was performed by conceptualization, classification, coding and component analysis (Spiers \& Riley, 2019). Coding is the process of revealing concepts appropriate to the meaning of the 
sentences in the data set (Mihas, 2019). In this process, the words highlighted in the sentence, word meanings are examined as a whole. The concepts introduced by coding are classified according to the topics. The concepts connected with each other as meaning and subject are combined (Riley et al., 2019).

\section{FINDINGS (RESULTS)}

\section{Demographic Characteristics}

This study aims to investigate the effects of menopause and menstruation on women's perception of aging. For this purpose, 11 questions were asked to the participants by an in-depth interview method. The answers to the five questions were presented in Table 1.

Table 1. The Relationship Between Menstruation and Age Perception

\begin{tabular}{|c|c|c|c|c|c|c|c|c|c|c|c|}
\hline Q2 & $f$ & $\%$ & Q3 & $f$ & $\%$ & Q4 & $f$ & $\%$ & Q5 & $f$ & $\%$ \\
\hline $\begin{array}{l}\text { Ruptured } \\
\text { Ovarian Cyst, } \\
\text { Vaginal } \\
\text { Burning }\end{array}$ & 4 & 33,4 & $\begin{array}{l}\text { Hormonal } \\
\text { Imbalance } \\
\mathrm{HI}\end{array}$ & 29 & 43,9 & $\begin{array}{l}\text { Hormonal } \\
\text { Imbalance }\end{array}$ & 28 & 42,4 & $\begin{array}{l}\text { Hormon } \\
\text { al } \\
\text { Imbalan } \\
\text { ce }\end{array}$ & 25 & $\begin{array}{l}37, \\
9\end{array}$ \\
\hline $\begin{array}{l}\text { Follicle- } \\
\text { Stimulating } \\
\text { Hormone } \\
\text { (FSH) Problem }\end{array}$ & 2 & 16,7 & $\begin{array}{l}\text { Fibroids, } \\
\text { Polyps } \\
\text { Cysts } \\
\text { FPC }\end{array}$ & 16 & 24,2 & Aging & 9 & 13,6 & $\begin{array}{l}\text { Pregnan } \\
\text { cy }\end{array}$ & 17 & $\begin{array}{l}25, \\
8\end{array}$ \\
\hline $\begin{array}{l}\text { Polycystic } \\
\text { Ovary } \\
\text { Syndrome } \\
\text { (PCOS) }\end{array}$ & 2 & 16,7 & $\begin{array}{l}\text { Aging } \\
\text { AGE }\end{array}$ & 8 & 12,1 & $\begin{array}{l}\text { Fibroids, } \\
\text { Polyps \& } \\
\text { Cysts }\end{array}$ & 9 & 13,6 & $\begin{array}{l}\text { Menopa } \\
\text { use }\end{array}$ & 9 & $\begin{array}{l}13, \\
6\end{array}$ \\
\hline $\begin{array}{l}\text { An Ectopic } \\
\text { Pregnancy }\end{array}$ & 1 & 8,3 & Other & 8 & 12,2 & Stress & 7 & 10,7 & $\begin{array}{l}\text { Polyps \& } \\
\text { Cysts }\end{array}$ & 7 & $\begin{array}{l}10, \\
6\end{array}$ \\
\hline $\begin{array}{l}\text { Fluid in the } \\
\text { Uterine Cavity }\end{array}$ & 1 & 8,3 & $\begin{array}{l}\text { Menopause } \\
\text { MEN }\end{array}$ & 5 & 7,6 & Climate & 5 & 7,6 & Aging & 5 & 7,6 \\
\hline Hysterectomy & 1 & 8,3 & & & & Pregnancy & 5 & 7,6 & Climate & 3 & 4,5 \\
\hline $\begin{array}{l}\text { Uterine } \\
\text { Fibroids }\end{array}$ & 1 & 8,3 & & & & Menopause & 3 & 4,5 & & & \\
\hline
\end{tabular}

Q1: Yes $(n=12 ; 18,2 \%)$, No $(n=54 ; 81,8 \%)$

The questions Q1 and Q2 aim to reveal whether the participants had a gynecological disease previously diagnosed by the doctor and if so, what were these diseases. According to the findings, $18.2 \%$ of the participants had a history of the female disease and $81.8 \%$ reported that they did not. The percentages of gynecological diseases reported by the participants were as follows: Ruptured ovarian cyst, Vaginal burning $(33,4 \%)$, Follicle-Stimulating Hormone (FSH) problem (16,7\%), Polycystic ovary syndrome (PCOS) (16,7\%), An ectopic pregnancy $(8,3 \%)$, Fluid in the uterine cavity $(8,3 \%)$, Hysterectomy $(8,3 \%)$, Uterine fibroids $(8,3 \%)$.

The question $\mathrm{Q} 3$ is aimed at revealing the issues related to the irregularity experienced during the menstruation period. According to the results, $43.9 \%$ of women stated that there was a relationship between hormonal imbalance and experiencing irregularity during the menstruation period. Other issues regarding the relationship are as follows: Fibroids, Polyps \& Cysts (24.2\%), aging (12.1\%), menopause (7.6\%). 
The question Q4 is aimed at revealing the issues related to the short-term or early period of menstruation. Similarly, with the Q3 question, $42.4 \%$ of the participants stated that there was a relationship between hormonal imbalance and short-term delay or early menstrual period. Other issues include as follows: aging $(13,6 \%)$, Fibroids, Polyps \& Cysts $(13,6 \%)$, stress $(10,7 \%)$, climate $(7,6 \%)$, pregnancy $(7,6 \%)$, Menopause $(4,5 \%)$.

Long term menstrual delay was inquired by the Q5 question to determine the change in menopause and aging perception. According to the results, $37.9 \%$ of the participants stated that there was a relationship between hormonal imbalance and long-term delay of menstrual period. Other related issues are as follows: Pregnancy $(25,8 \%)$, Menopause $(13,6 \%)$, Polyps \& Cysts $(10,6 \%)$, aging $(7,6 \%)$, climate $(4,5 \%)$.

Table 2. The Relationship Between Menstruation and Menopause

\begin{tabular}{llllll}
\hline Q6 & f & \% & Q7 & f & \% \\
\hline Aging & 34 & 51,5 & $\begin{array}{l}\text { Absence Of } \\
\text { Menstruation } \\
\text { (Amenorrhea) }\end{array}$ & 49 & 74,2 \\
Psychological Problems & 18 & 27,3 & $\begin{array}{l}\text { Menstrual } \\
\text { Irregularities }\end{array}$ & 15 & 22,7 \\
$\begin{array}{l}\text { Gynecological Diseases } \\
\text { Other }\end{array}$ & 10 & 15,2 & Aging & 1 & 1,5 \\
\hline
\end{tabular}

The Q6 question was asked to determine how the factors affecting menopause were perceived by the participants. $51.5 \%$ of the participants stated that aging was associated with menopause. Psychological problems $(27.3 \%)$ and gynecological factors (15.2\%) were other related issues. The perceptual dimension of the relationship between menstruation and menopause syndromes was measured with the Q7 question. $74.2 \%$ of the participants perceived the absence of menstruation as being associated with menopause. Besides, menstrual irregularities (22.7\%) were also determined as another related factor.

Table 3. The Relationship Between Menstruation and Perception of Aging

\section{Q8. The Reasons for the "Yes" Responses}

"Yes, I think the reason is the inevitable end of the natural cycle due to the decrease in female hormones as we go through the old age."

"I think there are exceptions, but due to certain hormone changes in old age when entering menopause, I know that menstrual irregularities may occur."

"With aging, the ovaries lose their previous function. It is getting old."

"Psychological weakness.",

"Generally, women over 45 years of age have menopause." "The cause of aging."

"Hormone changes as age progresses.", "Hormonal changes."

"The aging process starts due to problems in hormones."

"As the number and quality of eggs decreases in later ages, its formation decreases with time. Menstrual bleeding decreases as the number of eggs

\section{Main themes}

Aging

Aging

Aging \& Perception of Decline

Aging \& Perception of Decline

Aging

Aging

Aging \& Perception of Decline

Aging \& Perception of Decline

Aging \& Perception of Decline 
decreases."

"Psychology."

Perception of Decline

"Slow metabolism."

"Body hormonal change."

Perception of Decline

"Loss of hormones."

Perception of Decline

"Menopause occurs due to estrogen reduction."

Perception of Decline

Perception of Decline

Q8: Yes ( $n=23 ; 34,8 \%)$, No( $n=43 ; 65,2 \%)$

According to the results of the study, $34.8 \%$ of the participants stated that there was a relationship between menstruation and aging. The findings indicate that aging was perceived as a decline process by the participants who thought that there was a relationship between menstruation and aging and that decline perception was associated with symptoms during the menstruation period.

Table 4. The Relationship Between Menopause and Aging

\begin{tabular}{ll}
\hline Q9. The Reasons for the "Yes" Responses & Main Themes \\
\hline "Menopause usually begins with aging, but can be seen at a young age.", & Aging \\
"Menopause emerges as age progresses.", & Aging \\
"I think that body functions are decreasing in proportion to age.", & $\begin{array}{l}\text { Aging \& Perception of } \\
\text { Decline }\end{array}$ \\
"As the number and quality of eggs decrease in later ages, their formation & Aging \& Perception of \\
decreases over time. As the number of eggs decreases, menstrual bleeding & Decline \\
decreases. So I think it is related to aging.", & Aging \& Perception of \\
"Egg quality decreases with aging.", & $\begin{array}{l}\text { Decline } \\
\end{array}$ \\
"Due to the fully functioning biological clock.", & $\begin{array}{l}\text { Aging \& Perception of } \\
\text { Decline }\end{array}$ \\
"As the age progresses, our hormones start to work less and when they get older, & Aging \& Perception of \\
ovulation stops, which stops menstrual bleeding and triggers menopause.", & $\begin{array}{l}\text { Decline } \\
\text { Aging \& Perception of }\end{array}$ \\
"With age, our organs and hormones become passive." & Decline \\
& Perception of Decline \\
\hline
\end{tabular}

Q9: Yes (n=40; 60,2\%), No(n=26; 39,4\%)

According to the results of the study, $60.2 \%$ of the participants stated that there was a relationship between menopause and aging. The findings showed that aging was perceived as a decline process by the participants who thought that there was a relationship between menopause and aging, and this decline was associated with the symptoms of menopause.

Q10 and Q11 were asked to determine the mediating role of menopause on the perception of aging. The question Q10 measures whether the individual imitates the people around her about aging and the effect of imitation of elderly people's experiences on the perception of aging through self-assessment. The question Q11 measures whether a female imitates the people around her or not regarding menopause, and the effect of imitation of the experiences of people who are in the menopause process on menopause perception through self-assessment. 
Table 5. The Mediating Effect of Menopause on the Perception of Aging

\begin{tabular}{llllll}
\hline Q10 & $\mathbf{f}$ & $\mathbf{\%}$ & $\mathbf{Q 1 1}$ & $\mathbf{f}$ & $\mathbf{\%}$ \\
\hline Yes & 35 & 53 & Yes & 38 & 57,6 \\
No & 31 & 47 & No & 28 & 42,4 \\
\hline
\end{tabular}

According to the findings, $53 \%$ of the participants associate the problems of the people around them with aging and $57.6 \%$ of them associate their problems with menopause. More than $50 \%$ of women attach importance to knowledge gained from experiences around them. This thought increases the perception of the occurrence of the sampled event through internalization. This finding shows that the knowledge obtained through social learning is important for women. The perception of aging and menopause are compared and internalized with the acquired knowledge. This event in the cognitive process reveals the importance of internalization.

\section{CONCLUSION and DISCUSSION}

The emergence of the perception of aging through imitation has not been investigated in the literature. Researches focus on the psychological, social, economic and physical effects of aging (Lachman \& Agrigoroaei, 2010; Fiscella \& Franks, 1997; McTeer \& Curtis, 1990; Johnson et al., 2011). Research reveals that an individual's cognitive functions decline with aging (Ryan \& Burk, 1974; Ratcliff, Thapar \& McKoon, 2006; Hoyer \& Plude, 1980; Bayen \& Murnane, 1996; Rodrigue, Kennedy \& Raz, 2005). The relationship between perceptual effects and aging has been associated with age-related decline in cognitive dysfunction (Thapar \& McKoon, 2006; Hoyer \& Plude, 1980; Bayen \& Murnane, 1996). However, the results of these studies cannot explain the reasons for individuals' cognitive perception of aging.

According to the findings of the study, the experienced moods in the menstruation period such as sadness, irritability, anxiety, and anger were not related to the perception of aging, and the findings of menopause due to advancing age caused the perception of aging. The findings revealed that menopause could imitate the perception of aging and menstruation symptoms were effective in the emergence of this feature. There is no similar study in the literature regarding the findings of the study. The results clearly show that the perception of aging in women is affected by menopause and menstruation.

According to the findings of the study, it was found that the majority of the participants did not face with women's disease. When the effects of health on aging are considered, the effect of the perception of aging reveals its importance. The findings determined that almost half of the participants had a relationship between irregularity and hormonal imbalance during menstruation. On the other hand, nearly $40 \%$ of the participants stated that menopause was associated with hormonal imbalance and long-term delay of the menstrual period. When both findings were evaluated together, it was found that there was an important relationship between menopause and menstruation. 
According to the findings on the perception of the aging of women, nearly $40 \%$ of the participants stated that there was a relationship between menstruation and aging. On the other hand, more than $60 \%$ of the participants stated that menopause was related to aging. When all these findings are evaluated together, it is seen that menopause is associated with aging perception. The findings showed that aging was perceived as a decline process by the participants who thought that there was a relationship between menopause and aging, and this decline was associated with the symptoms of menopause.

It was revealed that menopause had the ability to imitate the perception of aging in women through cognitive learning. The ability to imitate was determined by the effect of menstruation symptoms on the perception of aging. When the questions that were asked to the participants and the results obtained after the systematic analysis of the responses were evaluated together, it was found that there was a significant relationship between menopause symptoms and aging. Finally, according to the findings on the mediating effect of menopause, it was revealed that more than half of the participants' perception of aging was due to the information obtained from their environment and menopause syndromes. This mediating effect revealed the ability to imitate an important effect. These results showed that individuals make sense of the information obtained through social learning by coding in the cognitive process, and they had the perception of aging by associating the information they associated with aging. Internalized information is shaped according to the perception of the individual. As a result of this shaping process, aging perception occurs. These results make a significant contribution to the findings that aging is a result of pathological and cognitive dysfunction.

\section{RECOMMENDATIONS}

These important effects of perception on aging should be investigated in the literature as multidisciplinary. The findings of the study reveal that the perceptual transformation resulting from social learning will provide a major contribution to the literature on education, technology acceptance, organizational behavior, and successful aging. It is recommended that research on the aging process of women should be increased and perception in aging should be evaluated together with successful aging. The fact that the findings of the study reveal the imitation ability of menopause in the context of age perception raises the concept of "latent aging".

The first study in this field is the study titled "Latent aging" by Özsungur (2019). It was found in this study that latent aging was associated with physical changes, palliative diseases, and chronic pain. This type of aging, called latent aging, is the condition in which individuals fall in aging syndrome as a result of the comparison of knowledge and experiences obtained through social learning from their environment. The imitation of menopause using the symptoms of menstruation is similar to the type of latent aging. For this reason, it is recommended for future studies to examine this type of aging in the context of menopause and menstruation. Besides, pathological findings that will be obtained as a result of clinical studies will contribute to the literature. 


\section{ETHICAL STATEMENT}

In this article, journal writing rules, publishing principles, research and publishing ethics rules, journal ethics rules are followed. The responsibility belongs to the author $(\mathrm{s})$ for any violations related to the article.

\section{REFERENCES}

Abramovitz, M. (2017). Regulating the Lives of Women: Social Welfare Policy from Colonial Times to the Present. Routledge.

Bancroft, J. (1995). The Menstrual Cycle and the Well Being of Women. Social Science and Medicine, 41(6), 785791.

Bayen, U. J. \& Murnane, K. (1996). Aging and the Use of Perceptual and Temporal Information in Source Memory Tasks. Psychology and Aging, 11(2), 293.

Byrne, M. (2001). Sampling for Qualitative Research. AORN journal, 73(2), 494-494.

Cameron, E., Ward, P., Mandville-Anstey, S. A. \& Coombs, A. (2019). The Female Aging Body: A Systematic Review of Female Perspectives on Aging, Health, and Body Image. Journal of Women \& Aging, 31(1), 317.

Clouston, S. A., Smith, D. M., Mukherjee, S., Zhang, Y., Hou, W., Link, B. G. \& Richards, M. (2019). Education and Cognitive Decline: An Integrative Analysis of Global Longitudinal Studies of Cognitive Aging. The Journals of Gerontology: Series $B$.

Condello, G., Capranica, L., Migliaccio, S., Forte, R., Di Baldassarre, A. \& Pesce, C. (2019). Energy Balance and Active Lifestyle: Potential Mediators of Health and Quality of Life Perception in Aging. Nutrients, 11(9), 2122.

Coveney, L., Jackson, M., Jeffreys, S., Kay, L. \& Mahony, P. (2019). The Sexuality Papers: Male Sexuality and the Social Control of Women. Routledge.

Crimmins, E. M., Shim, H., Zhang, Y. S. \& Kim, J. K. (2019). Differences Between Men and Women in Mortality and the Health Dimensions of the Morbidity Process. Clinical chemistry, 65(1), 135-145.

Dye, L., Warner, P. \& Bancroft, J. (1995). Food Craving During the Menstrual Cycle and its Relationship to Stress, Happiness of Relationship and Depression; a Preliminary Enquiry. Journal of Affective Disorders, 34(3), 157-164.

Fiscella, K. \& Franks, P. (1997). Does Psychological Distress Contribute to Racial and Socioeconomic Disparities in Mortality? Social Science \& Medicine, 45(12), 1805-1809.

Franceschi, C., Garagnani, P., Gensous, N., Bacalini, M. G., Conte, M. \& Salvioli, S. (2019). Accelerated Bio-Cognitive Aging in Down Syndrome: State of the Art and Possible Deceleration Strategies. Aging Cell, 18(3), e12903.

Gall MD, Barg, W. R. \& Gall, J. P. (1996). Educational Research: an Introduction 6th (edn.). New York: Longman. 
Gambacciani, M., Biglia, N., Cagnacci, A., DI Carlo, C., Caruso, S., Cicinelli, E. \& Lanzone, A. (2018). Menopause and Hormone Replacement Therapy. The 2017 Recommendations of the Italian Menopause Society. Minerva Ginecol, 70(1), 27-34.

Gerring J. (2004) What is a Case Study and What is it Good for?, American Political Science Review 98 (2), 341 354.

Golub, S. (2017). Lifting the Curse of Menstruation: A Feminist Appraisal of the Influence of Menstruation on Women's Lives. Routledge.

Goodwin, B. J., Interligi, C. J., Kasardo, A. E., McHugh, M. C. \& Poet, A. D. (2019). Who is the Woman in the Psychology of Women? Addressing Diversity and Intersectionality. In J. A. Mena \& K. Quina (Eds.), Integrating Multiculturalism and Intersectionality into the Psychology Curriculum: Strategies for Instructors (p. 51-62). American Psychological Association. https://doi.org/10.1037/0000137-005

Greer, G. (2018). The Change: Women, Ageing and the Menopause. Bloomsbury Publishing.

Gurera, J. W. \& Isaacowitz, D. M. (2019). Emotion Regulation and Emotion Perception in Aging: A Perspective on Age-Related Differences and Similarities. Progress in Brain Research, 247, 329-351.

Haines, S. J., Shelton, J. T., Henry, J. D., Terrett, G., Vorwerk, T. \& Rendell, P. G. (2019). Prospective Memory and Cognitive Aging. In Oxford Research Encyclopedia of Psychology.

Harlow, B. L., Wise, L. A., Otto, M. W., Soares, C. N. \& Cohen, L. S. (2003). Depression and its Influence on Reproductive Endocrine and Menstrual Cycle Markers Associated with Perimenopause: the Harvard Study of Moods and Cycles. Archives of General Psychiatry, 60(1), 29-36.

Hooker, K., Mejía, S. T., Phibbs, S., Tan, E. J. \& Stevens, J. (2019). Effects of Age Discrimination on SelfPerceptions of Aging and Cancer Risk Behaviors. The Gerontologist, 59 (Supplement_1), S28-S37.

Hosseini, A. S. S. (2018). Unpreparedness, Impurity and paradoxical Feeling: Menstruation Narratives of Iranian Women. International Journal of Adolescent Medicine and Health.

Hoyer, W. J. \& Plude, D. J. (1980). Attentional and Perceptual Processes in the Study of Cognitive Aging. In L. W. Poon (Ed.), Aging in the 1980s: Psychological Issues (p. 227-238). American Psychological Association. https://doi.org/10.1037/10050-016

Ismail, K., Pedro, A. \& Andipatin, M. (2016). Exploring a Sample of University Students' Perceptions of Menstruation. Journal of Psychology in Africa, 26(4), 394-396.

Jenraumjit, R., Chinwong, S., Chinwong, D., Kanjanarach, T., Kshetradat, T., Wongpakaran, T. \& Wongpakaran, N. (2020). Anticholinergics and Benzodiazepines on Cognitive Impairment Among Elderly with Alzheimer's Disease: A 1 Year Follow-Up Study. BMC Research Notes, 13(1), 1-6.

Johnstone, R. A. \& Cant, M. A. (2019). Evolution of Menopause. Current Biology, 29(4), R112-R115.

Johnson, W., Corley, J., Starr, J. M. \& Deary, I. J. (2011). Psychological and Physical Health at Age 70 in the Lothian Birth Cohort 1936: Links with Early Life IQ, SES, And Current Cognitive Function and Neighborhood Environment. Health Psychology, 30(1), 1.

Karim, R., Koc, M., Rettberg, J. R., Hodis, H. N., Henderson, V. W., John, J. A. S. \& Mack, W. J. (2019). Apolipoprotein E4 Genotype in Combination with Poor Metabolic Profile is Associated with Reduced 
Cognitive Performance in Healthy Postmenopausal Women: Implications for Late Onset Alzheimer's Disease. Menopause, 26(1), 7-15.

Karlsson, P., Thorvaldsson, V. \& Johansson, B. (2019). Birth Cohort Differences in Cognitive Aging: Secular Trends Over 30 Years in Three Swedish Samples. In IAGG-ER 2019.

Kittell, L. A., Mansfield, P. K. \& Voda, A. M. (1998). Keeping up Appearances: The Basic Social Process of the Menopausal Transition. Qualitative Health Research, 8(5), 618-633.

Koerber, A. \& McMichael, L. (2008). Qualitative Sampling Methods: A Primer for Technical Communicators. Journal of Business and Technical Communication, 22(4), 454-473.

Koeske, R. D. (2017). Lifting the Curse of Menstruation: Toward a Feminist Perspective on the Menstrual Cycle. in Lifting the Curse of Menstruation (pp. 1-16). Routledge.

Koff, E., Rierdan, J. \& Stubbs, M. L. (1990). Conceptions and Misconceptions of the Menstrual Cycle. Women \& Health, 16(3-4), 119-136.

Komanduri, M., Gondalia, S., Scholey, A. \& Stough, C. (2019). The Microbiome and Cognitive Aging: a Review of Mechanisms. Psychopharmacology, 1-13.

Lachman, M. E. \& Agrigoroaei, S. (2010). Promoting Functional Health in Midlife and Old Age: Long-Term Protective Effects of Control Beliefs, Social Support, and Physical Exercise. PloS one, 5(10), e13297.

Lamar, M., Boots, E. A., Arfanakis, K., Barnes, L. L. \& Schneider, J. A. (2020). Brain Structural Alterations Common to Cardiovascular Disease Risk Factors and Alzheimer's Dementia. Vascular Disease, Alzheimer's Disease, and Mild Cognitive Impairment: Advancing an Integrated Approach, 241.

Levine, M. E., Lu, A. T., Chen, B. H., Hernandez, D. G., Singleton, A. B., Ferrucci, L. \& Kusters, C. D. (2016). Menopause Accelerates Biological Aging. Proceedings of the National Academy of Sciences, 113(33), 9327-9332.

Levy, B. R. \& Myers, L. M. (2004). Preventive Health Behaviors Influenced by Self-Perceptions of Aging. Preventive Medicine, 39(3), 625-629.

Levy, B. R., Slade, M. D., Kunkel, S. R. \& Kasl, S. V. (2002). Longevity Increased by Positive Self-Perceptions of Aging. Journal of Personality and Social Psychology, 83(2), 261.

Levy, B. R., Slade, M. D. \& Kasl, S. V. (2002). Longitudinal Benefit of Positive Self-Perceptions of Aging on Functional Health. The Journals of Gerontology Series B: Psychological Sciences and Social Sciences, 57(5), P409-P417.

Manson, J. E. \& Kaunitz, A. M. (2016). Menopause Management-Getting Clinical Care Back on Track. New England Journal of Medicine, 374(9), 803-806.

Marshall, M. N. (1996). Sampling for Qualitative Research. Family Practice, 13(6), 522-526.

Martin, E. (1988). Medical Metaphors of Women's Bodies: Menstruation and Menopause. International Journal of Health Services, 18(2), 237-254.

Marván, M. L. \& Chrisler, J. C. (2018). Menarcheal Timing, Memories of Menarche, and Later Attitudes Toward Menstruation. Cogent Psychology, 5(1), 1525840. 
Maxwell J.A. (1996). Applied Social Research Methods Series, Qualitative Research Design: an Interactive Approach. Thousand Oaks, CA, US: Sage Publications 41.

McGannon, K. R., Schinke, R. J., Ge, Y. \& Blodgett, A. T. (2019). Negotiating Gender and Sexuality: a Qualitative Study of Elite Women Boxer Intersecting Identities and Sport Psychology Implications. Journal of Applied Sport Psychology, 31(2), 168-186.

McTeer, W. \& Curtis, J. E. (1990). Physical Activity and Psychological Well-Being: Testing Alternative Sociological Interpretations. Sociology of Sport Journal, 7(4), 329-346.

Meriwether, M. L. (2018). A Social History of Women and Gender in the Modern Middle East. Routledge.

Metcalf, M. G., Livesey, J. H., Wells, J. E., Braiden, V., Hudson, S. M. \& Bamber, L. (1991). Premenstrual Syndrome in Hysterectomized Women: Mood and Physical Symptom Cyclicity. Journal of Psychosomatic Research, 35(4-5), 555-567.

Meyvaci, S. S., Bamaç, B., Duran, B., Çolak, T. \& Memişoğlu, K. (2020). Effect of Surgical and Natural Menopause on Proximal Femur Morphometry in Obese Women. Annals of Anatomy-Anatomischer Anzeiger, 227, 151416.

Michael, J., Iqbal, Q., Haider, S., Khalid, A., Haque, N., Ishaq, R. \& Bashaar, M. (2020). Knowledge and Practice of Adolescent Females About Menstruation and Menstruation Hygiene Visiting a Public Healthcare Institute of Quetta, Pakistan. BMC Women's Health, 20(1), 1-8.

Mihas, P. 2019. Qualitative Data Analysis. In Oxford Research Encyclopedia of Education.

Mobarak, H., Heidarpour, M., Lolicato, F., Nouri, M., Rahbarghazi, R. \& Mahdipour, M. (2019). Physiological Impact of Extracellular Vesicles on Female Reproductive System; Highlights to Possible Restorative Effects on Female Age-Related Fertility. BioFactors.

Moeller, S. J., Goodwin, R. D., Sullivan, R. M. \& Verdejo-Garcia, A. (2020). Drug Use and Self-Awareness of Treatment Need: an Exemplar of How Population-Based Survey Studies Can Address Questions Relevant to the Neuroscience of Insight. In Cognition and Addiction (pp. 351-364). Academic Press.

Morse, C. A. \& Dennerstein, L. (1988). Cognitive therapy for Premenstrual Syndrome. In Functional Disorders of the Menstrual Cycle (pp. 177-190). John Wiley, Chichester.

Motro, D., Gabriel, A. S. \& Ellis, A. P. (2019). Examining the Effects of Menstruation on Women's Helping Behaviour in the Workplace. Journal of Occupational and Organizational Psychology.

Muhleisen, A. L. \& Herbst-Kralovetz, M. M. (2016). Menopause and the Vaginal Microbiome. Maturitas, 91, 4250.

Nelson, D. B., Sammel, M. D., Freeman, E. W., Lin, H., Gracia, C. R. \& Schmitz, K. H. (2008). Effect of Physical Activity on Menopausal Symptoms Among Urban Women. Medicine \& Science in Sports \& Exercise, 40(1), 50-58.

Parlee, M. B. (1976). Social Factors in the Psychology of Menstruation, Birth, and Menopause. Primary Care, 3(3), 477-490. 
Porter, M., Penney, G. C., Russell, D., Russell, E. \& Templeton, A. (1996). A Population Based Survey of Women's Experience of the Menopause. BJOG: An International Journal of Obstetrics \& Gynaecology, 103(10), 1025-1028.

Özsungur, F. (2019). Latent Aging. Biomedical Journal of Scientific \& Technical Research (BJSTR). 20(4)-2019. BJSTR. MS.ID.003497.

Parish, A., Kim, J., Lewallen, K. M., Miller, S., Myers, J., Panepinto, R. \& Maxwell, C. A. (2019). Knowledge and Perceptions About Aging and Frailty: An Integrative Review of the Literature. Geriatric Nursing, 40(1), $13-24$

Petkus, A. J., Filoteo, J. V., Schiehser, D. M., Gomez, M. E., Hui, J. S., Jarrahi, B. \& Petzinger, G. M. (2020). Mild Cognitive Impairment, Psychiatric Symptoms, and Executive Functioning in Patients with Parkinson's Disease. International Journal of Geriatric Psychiatry.

Prior, J. C. (2020). Postpartum Lactational Amenorrhea and Recovery of Reproductive Function and Normal Ovulatory Menstruation. In Maternal-Fetal and Neonatal Endocrinology (pp. 207-214). Academic Press.

Ratcliff, R., Thapar, A. \& McKoon, G. (2006). Aging, Practice, and Perceptual Tasks: a Diffusion Model Analysis. Psychology and aging, 21(2), 353.

Ray, S. \& Agarwal, P. (2020). Depression and Anxiety in Parkinson Disease. Clinics in Geriatric Medicine, 36(1), 93-104.

Reiber, C. (2010). Female Gamete Competition: a New Evolutionary Perspective on Menopause. Journal of Social, Evolutionary, and Cultural Psychology, 4(4), 215-240. https://doi.org/10.1037/h0099287

Reicher, L., Yogev, Y. \& Maslovitz, S. (2020). 730: Should Women Wait for the First Menstrual Period Following Spontaneous Miscarriage Before Becoming Pregnant Again?. American Journal of Obstetrics \& Gynecology, 222(1), S462.

Reid, R. L., Black, D., Derzko, C. \& Portman, D. (2020). Ospemifene: A Novel Oral Therapy for Vulvovaginal Atrophy of Menopause. Journal of Obstetrics and Gynaecology Canada.

Richardson, N. (2020). Your Period Handbook: Natural Solutions for Stress Free Menstruation. Karnac Books.

Riley, S., Brooks, J., Goodman, S., Cahill, S., Branney, P., Treharne, G., and Sullivan, C. 2019. Celebrations Amongst Challenges: Considering the Past, Present and Future of the Qualitative Methods in Psychology (QMiP) section of the British Psychological Society.

Roberts, J. G. (2019). Effects of Cognitive Aging on AMPA and NMDA Receptor Expression in CA3 and CA1 Pyramidal Neurons (Doctoral dissertation, Rush University).

Rodrigue, K. M., Kennedy, K. M. \& Raz, N. (2005). Aging and Longitudinal Change in Perceptual-Motor Skill Acquisition in Healthy Adults. The Journals of Gerontology Series B: Psychological Sciences and Social Sciences, 60(4), P174-P181.

Russell, J. K., Jones, C. K. \& Newhouse, P. A. (2019). The Role of Estrogen in Brain and Cognitive Aging. Neurotherapeutics, 1-17. 
Ryan, W. J. \& Burk, K. W. (1974). Perceptual and Acoustic Correlates of Aging in the Speech of Males. Journal of communication disorders, 7(2), 181-192.

Salthouse, T. A. (2019). Trajectories of Normal Cognitive Aging. Psychology and Aging, 34(1), 17.

Sanders, D., Warner, P., Backstrom, T. \& Bancroft, J. (1983). Mood, sexuality, Hormones and the Menstrual Cycle. I. Changes in Mood and Physical State: Description of Subjects and Method. Psychosomatic Medicine, 45(6), 487-501.

Sexton, C. E., Sykara, K., Karageorgiou, E., Zitser, J., Rosa, T., Yaffe, K. \& Leng, Y. (2019). Connections Between Insomnia and Cognitive Aging. Neuroscience Bulletin, 1-8.

Skultans, V. (1970). The Symbolic Significance of Menstruation and the Menopause. Man, 5(4), 639-651.

Smail, L., Jassim, G. \& Shakil, A. (2020). Menopause-Specific Quality of Life among Emirati Women. International Journal of Environmental Research and Public Health, 17(1), 40.

Smith, J. L. \& Bryant, F. B. (2019). Enhancing Positive Perceptions of Aging by Savoring Life Lessons. Aging \& Mental Health, 23(6), 762-770.

Sobhani, Z., Karimi, A., MoeinVaziri, N., Zare, A. \& Amini, M. (2019). A Pregnant Lady Undergoing Bariatric Surgery. Obesity surgery, 1-3.

Spiers, J., and Riley, R. 2019. Analysing one Dataset with Two Qualitative Methods: The Distress of General Practitioners, a Thematic and Interpretative Phenomenological Analysis. Qualitative Research in Psychology, 16(2), 276-290.

Spradley J. P. (1980). Participant Observation. Orlando FL: Harcourt Inc. Spreitzer GM Psychological Empowerment in the Workplace: Dimensions, Measurement, and Validation. Academy of Management Journal 38(5), 1442-1465.

Srivarathan, A., Jensen, A. N. \& Kristiansen, M. (2019). Community-Based Interventions to Enhance Healthy Aging in Disadvantaged Areas: Perceptions of Older Adults and Health Care Professionals. BMC Health Services Research, 19(1), 7.

Taskin, O., Gökdeniz, R., Muderrisoglu, H., Korkmaz, M. E., Uryan, I., Atmaca, R. \& Kafkasli, A. (1998). The Effects of Hormone Replacement Therapy on Echocardiographic Basic Cardiac Functions in Postmenopausal Women. Human Reproduction (Oxford, England), 13(9), 2399-2401.

Tenner, A. J. (2020). Complement-Mediated Events in Alzheimer's Disease: Mechanisms and Potential Therapeutic Targets. The Journal of Immunology, 204(2), 306-315.

Tilly, L. A. \& Scott, J. W. (2016). Women, Work and Family. Routledge.

Treloar, A. E. (1981). Menstrual Cyclicity and the Pre-Menopause. Maturitas, 3(3-4), 249-264.

Tucker-Drob, E. M. (2019). Cognitive Aging and Dementia: A Life-Span Perspective. Annual Review of Developmental Psychology, 1, 177-196.

Watson, L. B. (2019). Gender Identity and Expression in LGBTQ+ Communities: Implications for the Practice of Psychology. Psychology of Women Quarterly, 0361684319846498. 
Webb, C. E., Rodrigue, K. M., Hoagey, D. A., Foster, C. M. \& Kennedy, K. M. (2019). Contributions of White Matter Connectivity and BOLD Modulation to Cognitive Aging: A lifespan Structure-Function Association Study. Biorxiv, 620443.

Yu, J., Collinson, S. L., Liew, T. M., Ng, T. P., Mahendran, R., Kua, E. H. \& Feng, L. (2019). Super-Cognition in Aging: Cognitive Profiles and Associated Lifestyle Factors. Applied Neuropsychology: Adult, 1-7.

Zimmerman, E. \& Parlee, M. B. (1973). Behavioral Changes Associated with the Menstrual Cycle: An Experimental Investigation 1. Journal of Applied Social Psychology, 3(4), 335-344. 
Appendix 1. The Study Questions

\section{Order Questions}

Q1. Have you ever had gynecological diseases diagnosed by a doctor before?

Q2. What was your disease?

Q3. What kind of disease do you think you have when you experience irregularity during the menstruation period?

Q4. What do you think this is related when your period is delayed for a short period or when you have an early period?

Q5. What do you think this is related when your period is delayed for a long time?

Q6. What do you think about menopause? Which factors do you think cause menopause?

Q7. Which of the menstruation problems do you think is related to menopause?

Q8. Do you think menstruation is related to aging?

If yes, what kind of relationship is there?

Q9. Do you think menopause has a relationship with aging?

If yes, what kind of relationship is there?

Q10. When you experience the problems of the elderly people around you, do you feel that you are getting older?

Q11. When you experience the problems of a woman who has experienced menopause, do you think that you will go through menopause? 


\title{
MENSTRÜASYON DÖNEMININ MENOPOZ TAKLIDI VASITASIYLA YAŞLILIK ALGISI ÜZERINDEKI ETKILERI
}

\begin{abstract}
öz
Bu çalışmada menopoz ve menstrüasyonun kadınların yaşlılık algısına etkilerinin belirlenmesi amaçlanmıştır. Bu çalışma Ağustos 2019'da 66 kadın katılımcı ile gerçekleştirilmiştir (Türkiye'de Adana ilinde yaşayan; 79 kadından seçilmiştir). Bu çalışmada, yaşlılık algısının, katılımcıların yaşlılık belirtilerine maruz kalan yaşlılardan ve kendilerinden elde ettikleri bilgilerin karşılaştırılması ve içselleştirilmesi sonucunda ortaya çıktığı tespit edilmiştir. Menopoz yaşlılık algısı ile ilişsili iken menstrüasyon ve yaşlılık algısı arasındaki ilişki zayıftır. Menopoz ve menstrüasyonun yaşlılık ile ilişkili olduğunu düşünen katılımcılara göre yaşlılık bir gerileme sürecidir. Kadınlar çevrelerindeki insanları menopoz ve yaşlılık algısı konusunda taklit etmektedirler. Menopozun menstrüasyonun yaşlılık algısı üzerindeki etkisini taklit etme yeteneğ belirlenmiştir. Menopozun bilişsel öğrenme yoluyla kadınlarda yaşlılık algısını taklit edebildiği ortaya konulmuştur. Taklit etme yeteneği, menstrüasyonun belirtilerinin yaşlıık algısına etkisi ile belirlenmiştir. Örneklemin Adana iliyle sınırlandırılmış olması çalışmanın genellenebilirliğini sınırlandırmıştır. Bu çalışma, menstrüasyon döneminin menopozun yaşlılık ve taklit algısı üzerindeki etkilerini ortaya koyan ilk çalışmadır. Teorik çerçeve, tartışma, yönetsel çıkarımlar, sınırlamalar ve gelecekteki çalışmalar için öneriler bu çalışmada tartışılmıştır.
\end{abstract}

Anahtar Kelimeler: Menstrüasyon dönemi, menopoz, yaşlılığın taklidi, gerontoloji, yaşlılık. 


\section{GiRiş}

Biyolojik özellikleri nedeniyle kadınlar ergenlikle birlikte bazı önemli değişiklikler yaşamaktadır. Bu değişikliklerden ikisi menstrüasyon ve menopozdur. Menstrüasyon, 3-7 gün arasında değişen, biyolojik gelişim nedeniyle 11 ila 14 yaşından başlayarak menopoza kadar devam eden kadınların üreme döngülerini sağlayan hemorajik bir biyolojik olaydır (Dye, Warner ve Bancroft, 1995; Bancroft, 1995). Vajinadan kan tahliyesi ve psikolojik etkiler nedeniyle günlük yaşam kalitesi olumsuz etkilenir. Menstrüel kramplar (dismenore) menstrüasyondaki en yaygın sendromlardan biridir. Bu ağrılar servikal stenoz, psikolojik bozukluklar ve endometriozis nedeniyle ortaya çıkabilir (Zimmerman ve Parlee, 1973; Sanders vd., 1983).

Karın veya pelvik kramp ağrısı, baş ağrısı, adet öncesi sendrom, gıda veya tatlı isteği, şişkinlik, bel ağrısı, ruh hali değişimleri, göğüs ağrıları, yorgunluk, adet öncesi disforik bozukluk (gerginlik, sinirlilik, depresyon belirtileri) klinik olarak belirlenen menstrüasyon belirtileridir (Metcalf vd., 1991). Menopoz sırasında yumurtalıklardaki folikül miktarı ve sonuç olarak östrojen üretimi azalır. Zamanla östrojen üretimi sona erer ve yumurtalıklar küçülür. Sonuç olarak, adet döngüsü sona erer ve üreme yeteneği kaybedilir. Bu olaylar bir süreçte meydana gelir (Reiber, 2010; Treloar, 1981).

Menopozun premenopoz, menopoz ve postmenopoz olmak üzere üç temel dönemi bulunmaktadır. Premenopoz, adet düzensizliklerinin ortaya çıktığı ve yumurtalıklarda folikül aktivitesinin azaldığı bir dönemdir. Menstrüel kanama menopoza geçiş aşamasında durur. Bu işlemden sonra, amenore en az bir yıl boyunca ortaya çıkar. Her üç sürecin de önemli biyolojik, fiziksel ve psikolojik etkileri vardır (Nelson vd., 2008; Harlow vd., 2003; Koff, Rierdan ve Stubbs, 1990).

Araştırmalar, östrojen seviyelerindeki azalmanın ruh hali değişikliklerine yol açtığını göstermiştir. Yüz ve boyundaki damarların genişlemesinden kaynaklanan vazomotor semptomlar sıcak basması ve gece terlemelerine neden olur. Bu süreçte atrofik ve psikolojik değişiklikler meydana gelebilir. Bu psikolojik faktörler kadınların birbirlerinden edindikleri bilgilerden olumsuz etkilenmelerine neden olabilir (Porter vd., 1996; Taskin vd., 1998; Kitell, Mansfield ve Voda, 1998). Literatürdeki araştırmalar menopoz ve menstrüasyonun psikolojik sonuçlarına odaklanmıştır, ancak bu sonuçların algısal sonuçları göz ardı edilmiştir. Farklı yaş gruplarındaki kadınlardan ve internetten menopoz ile ilgili edindikleri bilgileri kendi vücutlarındaki değişikliklerle karşılaştırmak önemli sorunlar ortaya çıkarabilir (Morse ve Dennerstein, 1988). Ayrıca, artan yaştan kaynaklanan menopozun yaşlanma algısı oluşturup oluşturmadığı başka bir olgudur.

Yaşlanma algısı, bireyin yaşlılığa bağlı psikolojik durumunu etkileyen önemli bir konudur (Levy vd., 2002; Levy ve Myers, 2004). Algı, bireyin davranışını kontrol eden bir faktördür ve fiziksel ve sosyal çevreden etkilenir (Levy, Slade ve Kasl, 2002; Hooker vd., 2019). Etkili yönetim vasıtasıyla kontrol edilebilecek algılar, yaşlılık süreci yönetimi üzerinde önemli bir etkiye sahiptir (Srivarathan, Jensen ve Kristiansen, 2019; Smith ve Bryant, 2019). Çalışmalar, algılamanın yaşlanma sürecini yönetmede önemli bir faktör olduğunu göstermektedir (Condello ve 
ark., 2019; Parish vd., 2019; Gurera ve Isaacowitz, 2019). Bilişsel yaşlanma, bu bağlamda ortaya çıkan teorik bir yaklaşımdır (Salthouse, 2019; Franceschi vd., 2019).

Bilişsel yaşlanma, sosyal ve fiziksel çevrenin etkisi altındaki bireylerin yaşlanma sürecinde bellek, bilginin kodlanması, inhibisyon, hatırlama, akıl yürütme, dikkat, duygu kontrolü ve yaratıcılık gibi işlevlerin azalmasını içerir (Clouston vd., 2019; Haines vd., 2019). Yaşlandıkça, psikolojik, duygusal ve fiziksel gerilemeler bireyler üzerindeki olumsuz etkilerini yavaş yavaş arttırır. Emekli olduktan sonra sosyal yaşama aktif katılım azalır ve birey sağlık sorunları nedeniyle yalnızlığa itilir (Komanduri vd., 2019; Karlsson, Thorvaldsson ve Johansson, 2019). Böylece yaşamdan çekilmeye başlayan kişi psikolojik ve patolojik hastalıklarını görmezden gelebilir ve ihmal edebilir (Sexton vd., 2019). Bu tutum ve davranışlar bireyin yaşam işlevlerinin azalmasına neden olur. Bilişsel fonksiyonlar bu gerilemelerden önemli ölçüde etkilenmektedir (Russell, Jones ve Newhouse, 2019; Tucker-Drob, 2019; Roberts, 2019; Yu vd., 2019; Webb vd., 2019).

Alzheimer ve Parkinson hastalıkları, yaşlılarda bilişsel düşüş, algısal sürece verilen hasarın bir sonucu olarak ortaya çıkar (Lamar vd., 2020; Tenner, 2020; Ray ve Agarwal, 2020; Petkus vd., 2020). Bilişsel bozukluk, ilaçların kötüye kullanılması, depresyon, demans, endokrin düzensizliklerinden kaynaklanmaktadır (Jenraumjit vd., 2020). Gerilemeler bilişsel yeteneklerin kullanımını önler. Saklanan bilgileri hatırlama ve kodlama hataları hatırlamayı zorlaştırır. Depresyon ve anksiyete gibi psikolojik sorunlar bu durumu tetikleyebilir (Moeller vd., 2020). Bu nedenle bireyin hayatı boyunca yaşadığı olaylar, sağlık sorunları ve sosyal baskı bu süreçte etkilidir.

Kadınlarda bilişsel yaşlanma, jinekolojik hastalıklar, çocuk bakımı, hamilelik, menstrüasyon, menopoz, ayrımcılık, sosyal baskı, tacize ve tecavüze maruz kalma gibi faktörler altında gelişir (Sobhani vd., 2019; Prior, 2020). Hamilelik kadınlarda önemli fiziksel ve duygusal değişiklikler yaratır (Reicher, Yogev ve Maslovitz, 2020; Richardson, 2020; Michael vd., 2020). Sahiplik duygusu geliştiren kadınların psikolojik olarak savunmacı bir kişiliği vardır (Goodwin vd., 2019). Bu değişiklikler bireyin sosyal uyumunu olumsuz yönde etkileyebilir (McGannon vd., 2019). Kadınların sosyal çevrelerine göre maruz kaldıkları sosyal baskılar psikolojilerini de olumsuz yönde etkilemektedir (Watson, 2019; Tilly ve Scott, 2016). Erken yaşlarda evlilik, aile içi şiddet, kadınların düşük kas gücü ve ekonomik bağımsızlığın olmaması gibi nedenler kadınların bilişsel yaşlanmasını etkiler (Coveney vd., 2019; Meriwether, 2018; Abramovitz, 2017).

Menstrüasyon, kadınların bilişsel yaşlanmasını olumsuz yönde etkileyen faktörlerden biridir (Golub, 2017). Menstrüasyon ergenlik döneminde ortaya çıkan kanamalı ve ağrılı bir dönemdir (Koeske, 2017). Bu dönemde kadınlar günlük yaşamlarında birçok zorlukla karşılaşırlar. Özellikle kanama nedeniyle ped kullanmak zorunda olan kadınlar yüzme ve spor gibi aktivitelerde önemli zorluklarla karşılaşmaktadır (Motro, Gabriel ve Ellis, 2019). Öte yandan, kadınlar adet dönemlerinde psikolojik sinirlilik ve kaygı yaşarlar (Marván, M. L. ve Chrisler, 2018). Menstrüasyon sırasında yaşanan düzensizlikler, genital bölgede aşırı kanama, ağrı ve yanıklar yaşam kalitesini azaltır (Hosseini, 2018). Tüm bu etkiler, yaşlanma sürecinde kadınların psikolojik tükenmesine yol açabilir (Ismail, Pedro ve Andipatin, 2016). Ayrıca, jinekolojik hastalıkların neden olduğu sağlık sorunları, bu yaşlanma 
sürecini başarılı bir şekilde yönetmelerini engelleyebilir (Cameron vd., 2019; Mobarak vd., 2019; Crimmins vd., 2019; Karim vd., 2019).

Menopoz, kadınlarda bir yıl boyunca menstrüasyon kanamasının olmamasıdır (Reid vd., 2020). Bu dönem kadınların yaşlılığa adım attığı önemli bir dönemdir (Smail, Jassim ve Shakil, 2020). Bu durum genellikle 45 yaş ve üzerinde görülür (Muhleissen ve Herbst-Kralovetz, 2016). Sıcak basması, terleme, halsizlik, unutkanlık, çarpıntı, anksiyete, sinirlilik, vajinal enfeksiyonlar bu dönemde ortaya çıkan semptomlardır (Gambacciani vd., 2018). Kadınlar menopoza benzer şekilde menstrüasyon sırasında yaşadıkları bazı semptomları yaşayabilirler (Meyvaci vd., 2020). Kadınların hayata aktif katılımını etkileyen menopoz, yaşlanma algısına neden olabilir (Levine vd., 2016). Araştırmalar, kadınların menopoz algılarının yaşlanma ile ilişkili olabileceğini göstermiştir. Yaşlılığa girerken ortaya çıkan menopoz, bireyin yaşlanma algısını ortaya çıkarabilir (Greer, 2018; Manson ve Kaunitz, 2016; Johnstone ve Cant, 2019). Ancak literatürde menopozun genel olarak yaşlanma öncesi ortaya çıkması ile adet dönemi arasındaki ilişki araştırılmamıştır.

Menstrüasyon ve menopoz, kadınların yaşam kalitesini ve refahını etkileyen iki önemli konudur (Skultans, 1970). Bu konular kadınların iş ve sosyal yaşamlarında önemli psikolojik, fiziksel ve psikososyal sonuçlarla karşılaşmasına neden olabilir. Bu sonuçlardan biri de yaşlanma algısıdır. Yaşlanma sürecinde menstrüasyon ve menopoz vasıtasıyla tecrübe edinilen sorunlar nedeniyle yaşlılık algılaı ve başarılı yaşlanma, araştırılması gereken güncel konulardır (Martin, 1988; Parlee, 1976). Bu çalışmada menstrüasyon ve menopozun fiziksel ve biyolojik etkilerine maruz kalarak günlük yaşamını sürdürmek zorunda olan kadınların yaşlanma algısı ve başarılı yaşlanmaları araştırılmıştır.

\section{YÖNTEM}

\section{Çalışmanın Amacı}

Bu çalışmada, menstrüasyon algılarının yaşlanma üzerindeki etkisinde menopozun rolünün tespit edilmesi amaçlanmıştır. Ayrıca çalışma, kadınların algısını etkileyen ve kadınları önemli ölçüde etkileyen menopoz ve menstrüasyon dönemlerini incelemeyi amaçlamaktadır. Kadınların erkeklere göre anatomik farklılıkları göz önüne alındığında, yaşlanma algısının araştırılması literatüre önemli katkılar sağlayacaktır. Özellikle menstrüasyon ve menopoz dönemlerinin kadınlara belirli özellikler açısından etkileri yaşlanma bağlamında incelenmemiştir. Bu, yaşlanma algısı ile menstrüasyon ve menopoz dönemleri arasındaki ilişkiyi inceleyen ilk nitel çalışmadır. Çalışmanın bulgularının aile ve tüketici bilimlerine, kadın çalışmalarına, jinekoloji, sosyal gerontoloji, sosyal hizmet ve yaşlılık çalışmalarına önemli katkılar sağlayacağı düşünülmektedir. Menopozun yaşlanma algısında aracı rolü, kadınların yaşlanma algılarını anlamada önemli katkılar sağlayacaktır.

Çalışmamızın hedef kitlesi, menstrüasyon ve menopoz arasında bir geçiş süreci oluşturan 35-50 yaş aralığındaki kadınlardır. Çünkü bu yaş aralığında kadınların yaşlanma algıları daha açık olmaya başlamaktadır. Ayrıca adet dönemleri sona ermekte ve menopoza geçiş dönemi başlamaktadır. Bu bağlamda, araştırma sorusu şu şekilde 
oluşturulmuştur: "Menopozun kadınlarda yaşlanma algıları üzerindeki etkisinde bir aracı rolü var mıdır?", "Bu aracı rolü bir taklit yeteneğini ortaya çıkarıyor mu?"

\section{Örneklem}

Çalışmanın hedef kitlesi kadınlar olduğundan ve bu nüfusa ulaşmakta güçlük çekildiği için evren ve örneklem seçimi daraltılmıştır. Bu nedenle çalışmada amaçlı ve rastgele örnekleme yöntemi tercih edilmiştir (Byrne, 2001; Marshall, 1996; Koerber ve McMichael, 2008). Illk olarak Adana ilinde bir işte çalışan kadınlar seçilmiş ve resmi kurumlarda çalışan bir alt grup oluşturulmuştur. Böylece örneklemi seçmek daha kolay hale gelmiştir. Literatürde önerilen örnek sayısı 5-25 arasında değişmektedir (Marshall, 1996; Koerber ve McMichael, 2008). Bu çalışma Ağustos 2019'da 66 kadın katılımcı ile gerçekleştirilmiştir (Türkiye'de Adana ilinde yaşayan; 79 kadın arasından seçilmiştir; yaşları 35-48 arasındadır). Ancak 13 katılımcı araştırmaya katılmayı reddetti. Çalışma resmi bir kurumda gerçekleştirildi. Kurum, adının açıklanmasına izin vermedi. Katılımcıların bu araştırma için izinleri alınmıştır.

\section{Veri Toplama Aşamasında Kullanılan Yöntem}

Bu çalışmada nitel araştırma yöntemi ve çoklu vaka tasarımı benimsenmiştir. Yapılandırıımış görüşme, veri toplama yaklaşımı ve gözlem teknikleri kullanılmıştır (Gerring, 2004). Önceden belirlenmiş sorular tüm katıımcılara aynı sırayla sorulmuştur (Gall, Barg ve Gall, 1996). Nitel veriler, sistematik hatayı en aza indirmek için bu alanda daha önce çalışmamış bir akademisyen tarafından analiz edilmiştir (Maxwell, 1996). Veri analizinde sırasıyla kavramsallaştırma, sınıflandırma ve bileşen analizi uygulanmıştır (Spradley, 1980). Katılımcılara toplam on bir soru soruldu (Ek 1). On bir soru, ilişkileri ortaya çıkarmayı amaçlayan, bireylerin geçmiş deneyimlerinden elde edilen bilgilere dayanmaktadır. Sorular sorulduktan sonra, bireylerden bir doktor tarafından teşhis edilen jinekolojik hastalıkların tıbbi raporlarını sunmaları istendi. Raporlar cevaplarla karşılaştırıldı.

\section{Verilerin Analizi}

Nitel verilerin analizinde, kavram haritalama tekniklerini içeren MAXQDA ve Voyant Tools programları kullanılmıştır. Verilerin analizi, sistematik hata riskini en aza indirmek için çalışma alanına dahil olmayan iki akademisyen tarafından değerlendirilmiştir. Değerlendirmeler karşılaştıııımış, farklılıklar analiz edilmiş ve ortak sonuçlar rapor edilmiştir. Veriler geleneksel yöntemle işlenmiş ve analiz edilmiştir. Veri analizi kavramsallaştırma, sınıflandırma, kodlama ve bileşen analizi ile gerçekleştirilmiştir (Spiers ve Riley, 2019). Kodlama, veri kümesindeki cümlelerin anlamlarına uygun kavramları ortaya çıkarma sürecidir (Mihas, 2019). Bu süreçte, cümlede vurgulanan kelimeler, kelime anlamları bir bütün olarak incelenir. Kodlama ile ortaya konulan kavramlar konulara göre sınıflandırıır. Anlam ve konu olarak birbiriyle bağlantılı kavramlar birleştirilir (Riley vd., 2019). 


\section{BULGULAR}

\section{Demografik Özellikler}

Bu çalışmada menopoz ve menstrüasyonun kadınların yaşlanma algısı üzerindeki etkileri araştırıldı. Bu amaçla katılımcılara derinlemesine mülakat yöntemi ile 11 soru yöneltilmiştir. Beş sorunun cevapları Tablo 1'de sunulmuştur.

Tablo 1. Menstrüasyon ve Yaş Algısı Arasındaki iliş̧ki

\begin{tabular}{|c|c|c|c|c|c|c|c|c|c|c|c|}
\hline Q2 & $f$ & $\%$ & Q3 & $f$ & $\%$ & Q4 & $f$ & $\%$ & Q5 & $f$ & $\%$ \\
\hline $\begin{array}{l}\text { Yumurtalık } \\
\text { Kisti, Vajinal } \\
\text { Yanma }\end{array}$ & 4 & 33,4 & $\begin{array}{l}\text { Hormonal } \\
\text { Imbalance } \\
\mathrm{HI}\end{array}$ & 29 & 43,9 & $\begin{array}{l}\text { Hormonal } \\
\text { Düzensizlik }\end{array}$ & 28 & 42,4 & $\begin{array}{l}\text { Hormon } \\
\text { al } \\
\text { Düzensiz } \\
\text { lik }\end{array}$ & 25 & $\begin{array}{l}37, \\
9\end{array}$ \\
\hline $\begin{array}{l}\text { Folikül Uyarıcı } \\
\text { Hormon (FSH) } \\
\text { Sorunu }\end{array}$ & 2 & 16,7 & $\begin{array}{l}\text { Fibroids, } \\
\text { Polyps ve } \\
\text { Cysts } \\
\text { FPC }\end{array}$ & 16 & 24,2 & Yaşlılık & 9 & 13,6 & $\begin{array}{l}\text { Hamileli } \\
\text { k }\end{array}$ & 17 & $\begin{array}{l}25, \\
8\end{array}$ \\
\hline $\begin{array}{l}\text { Polikistik Over } \\
\text { Sendromu } \\
\text { (PCOS) }\end{array}$ & 2 & 16,7 & $\begin{array}{l}\text { Aging } \\
\text { AGE }\end{array}$ & 8 & 12,1 & $\begin{array}{l}\text { Miyomlar, } \\
\text { Polipler ve } \\
\text { Kistler }\end{array}$ & 9 & 13,6 & $\begin{array}{l}\text { Menopo } \\
z\end{array}$ & 9 & $\begin{array}{l}13, \\
6\end{array}$ \\
\hline Dış Gebelik & 1 & 8,3 & Other & 8 & 12,2 & Stres & 7 & 10,7 & $\begin{array}{l}\text { Polipler } \\
\text { ve } \\
\text { Kistler }\end{array}$ & 7 & $\begin{array}{l}10, \\
6\end{array}$ \\
\hline $\begin{array}{l}\text { Rahim } \\
\text { Boşluğunda } \\
\text { Sıvı }\end{array}$ & 1 & 8,3 & $\begin{array}{l}\text { Menopause } \\
\text { MEN }\end{array}$ & 5 & 7,6 & İklim & 5 & 7,6 & Yaşlılık & 5 & 7,6 \\
\hline $\begin{array}{l}\text { Histerektomi } \\
\text { Uterin } \\
\text { Fibroidler }\end{array}$ & $\begin{array}{l}1 \\
1\end{array}$ & $\begin{array}{l}8,3 \\
8,3\end{array}$ & & & & $\begin{array}{l}\text { Hamilelik } \\
\text { Menopoz }\end{array}$ & $\begin{array}{l}5 \\
3\end{array}$ & $\begin{array}{l}7,6 \\
4,5\end{array}$ & İklim & 3 & 4,5 \\
\hline
\end{tabular}

Q1: Evet ( $n=12 ; 18,2 \%)$, Hayır ( $n=54 ; 81,8 \%)$

Q1 ve Q2 soruları, katılımcıların daha önce doktor tarafından teşhis edilmiş bir jinekolojik hastalığa sahip olup olmadığını ve eğer öyleyse, bu hastalıkların neler olduğunu ortaya koymayı amaçlamaktadır. Bulgulara göre, katılımcıların \% 18.2'sinde kadın hastalığı öyküsü vardı ve \% 81.8'inde olmadığı bildirilmiştir. Katılımcılar tarafından bildirilen jinekolojik hastalıkların yüzdeleri şu şekildedir: Yumurtalık kisti, vajinal yanma $(\%$ 33,4), folikül uyarıcı hormon (FSH) problemi (\% 16,7), polikistik over sendromu (PCOS) (\% 16, 7), dış gebelik (\% 8,3), rahim boşluğunda sıvı (\% 8,3), histerektomi (\% 8,3), uterin fibroidler (\% 8,3).

Q3, adet döneminde yaşanan düzensizlikle ilgili konuları ortaya çıkarmayı amaçlamaktadır. Sonuçlara göre, kadınların \% 43.9'u hormonal dengesizlik ile menstrüasyon dönemindeki düzensizlik deneyimi arasında bir ilişki olduğunu belirtmiştir. İlişki ile ilgili diğer konular şunlardır: Fibroidler, polipler ve kistler (\% 24.2), yaşlanma (\% 12.1), menopoz (\% 7.6).

Q4, menstrüasyonun kısa veya erken dönemiyle ilgili sorunları ortaya çıkarmayı amaçlamaktadır. Benzer şekilde, Q3 sorusu ile katılımcıların \% 42.4'ü hormonal dengesizlik ile menstrüasyon döneminde kısa süreli 
gecikme veya erken menstrüasyon dönemi arasında bir ilişki olduğunu belirtmiştir. Diğer konular şunlardır: Yaşlanma (\% 13,6), fibroidler, polipler ve kistler (\% 13,6), stres (\% 10,7), iklim $(\% 7,6)$, gebelik $(\% 7,6)$, menopoz $(\%$ 4,5).

Menopoz ve yaşlanma algısındaki değişikliği belirlemek için uzun dönem menstrual gecikme Q5 sorusu ile araştırıldı. Sonuçlara göre, katılımcıların \% 37.9'u hormonal dengesizlik ile adet döneminin uzun süreli gecikmesi arasında bir ilişki olduğunu belirtmiştir. Illgili diğer konular şunlardır: Gebelik (\% 25,8), menopoz $(\%$ 13,6), polipler ve kistler (\% 10,6), yaşlanma $(\% 7,6)$, iklim $(\% 4,5)$.

Tablo 2. Menstrüasyon ve Menopoz Arasındaki İlişki

\begin{tabular}{llllll}
\hline Q6 & f & \% & Q7 & f & \% \\
\hline Yaşlılık & 34 & 51,5 & $\begin{array}{l}\text { Menstrüasyonun } \\
\text { Yokluğu } \\
\text { (Amenore) }\end{array}$ & 49 & 74,2 \\
Psikolojik Problemler & 18 & 27,3 & $\begin{array}{l}\text { Menstrual } \\
\text { Düzensizlikler }\end{array}$ & 15 & 22,7 \\
$\begin{array}{l}\text { Jinekolojik Hastalıklar } \\
\text { Diğer }\end{array}$ & 10 & 15,2 & $\begin{array}{l}\text { Yaşlılık } \\
\text { Diğer }\end{array}$ & 1 & 1,5 \\
\hline
\end{tabular}

Q6 sorusu, menopozu etkileyen faktörlerin katılımcılar tarafından nasıl algılandığını belirlemesi için sorulmuştur. Katılımcıların \% 51.5'i yaşlanmanın menopoz ile ilişkili olduğunu belirtmiştir. Psikolojik sorunlar (\% 27.3) ve jinekolojik faktörler (\% 15.2) diğer ilişkili konulardır. Menstrüasyon ve menopoz sendromları arasındaki ilişkinin algısal boyutu Q7 sorusu ile ölçülmüştür. Katılımcıların \% 74.2'si menstrüasyonun yokluğunu menopozla ilişkili olarak algılamıştır. Ayrıca, menstrüasyon düzensizlikleri (\% 22.7) başka bir ilişkili faktör olarak belirlenmiştir.

Tablo 3. Menstrüasyon ve Yaşlılık Algısı Arasındaki İlişski

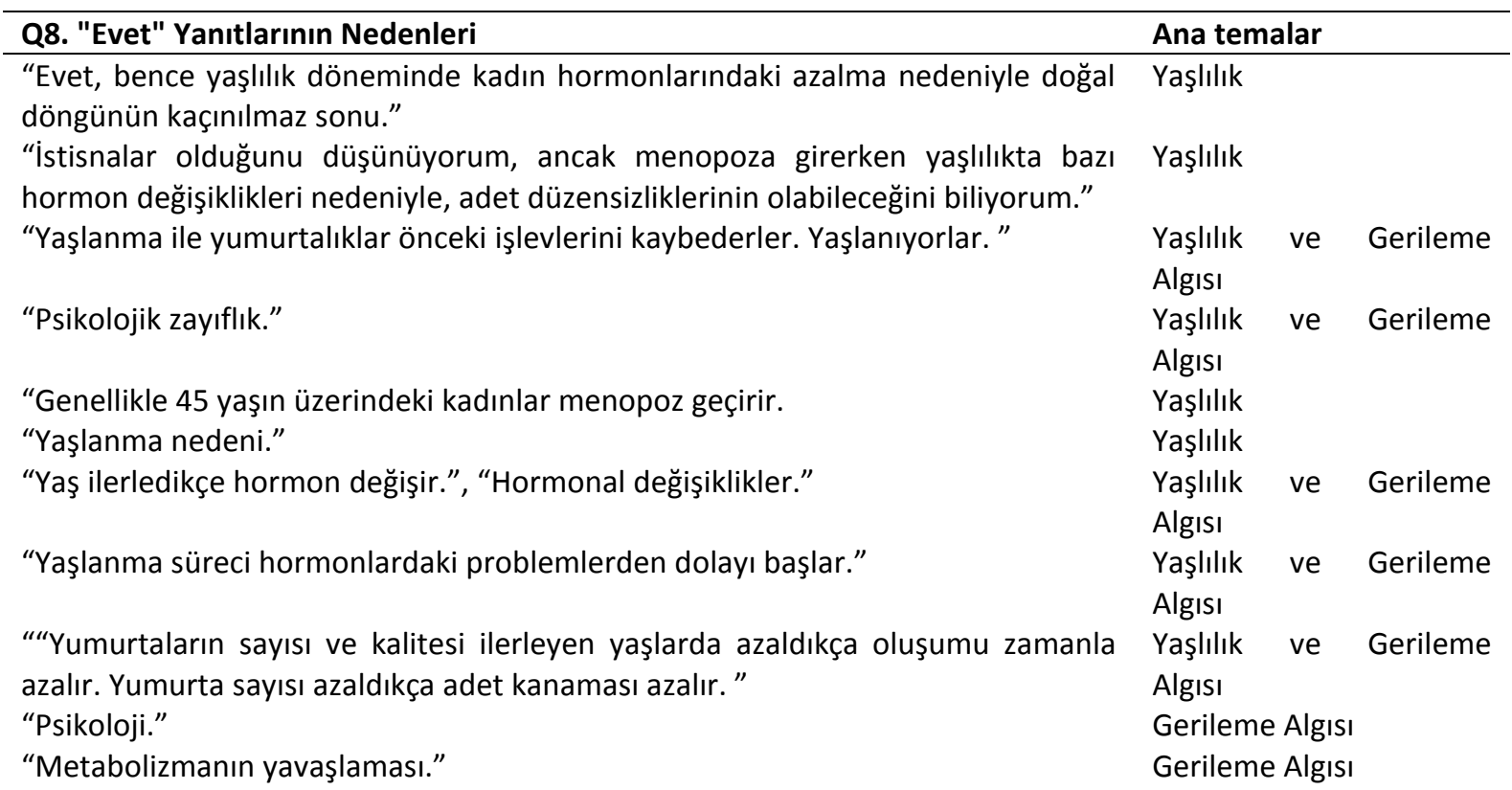


"Vücuttaki hormonel değişim."

Gerileme Algısı

"Hormon kaybı."

Gerileme Algısı

"Menopoz östrojen azalması nedeniyle oluşur."

Gerileme Algısı

Q8: Evet ( $n=23 ; 34,8 \%)$, Hayır $(n=43 ; 65,2 \%)$

Çalışmanın sonuçlarına göre, katılımcıların\% 34.8'i menstrüasyon ve yaşlılık arasında bir ilişki olduğunu belirtmiştir. Bulgular, menstrüasyonun yaşlanma ile ilişki olduğunu düşünen katılımcılar tarafından yaşlılığın bir gerileme süreci olarak algılandığını ve bu gerileme algısının menstrüasyon dönemi semptomlarıyla ilişkili olduğunu göstermektedir.

Tablo 4. Menopoz ve Yaşlanma Arasındaki İlişki

\section{Q9. "Evet" Yanıtlarının Nedenleri}

"Menopoz genellikle yaşlanma ile başlar, ancak genç yaşta da görülebilir.",

"Menopoz yaş ilerledikçe ortaya çıkar."

"Vücut işlevlerinin yaşla orantılı olarak azaldığını düşünüyorum.",

Ana temalar
Yaşıııık
Yaşısıık
Yaşııık ve Gerileme
Algısı
Yaşlılık ve Gerileme
Algısı
Yaşlılık ve Gerileme
Algısı
Yaşlıık ve Gerileme
Algısı
Yaşıııık ve Gerileme
Algısı
Yaşlılık ve Gerileme
Algısı
Gerileme Algısı

"Yumurtaların sayısı ve kalitesi ilerleyen yaşlarda azaldıkça oluşumları zamanla azalır. Yumurta sayısı azaldıkça adet kanaması azalır. Bu yüzden yaşlanma ile ilgili olduğunu düşünüyorum.",

"Yaşlandıkça yumurta kalitesi azalır.",

"Tamamen biyolojik saat işlemektedir."

Algısı

"Yaş ilerledikçe hormonlarımız daha az çalışmaya başlar ve yaşlandıkça adet kanamasını durduran ve menopozu tetikleyen yumurtlama durur.",

"Yaşlandıkça organlarımız ve hormonlarımız pasifleşir."

"Bence rahim ömrünü doldurmuş oluyor",

Q9: Evet ( $n=40 ; 60,2 \%)$, Hayır ( $n=26 ; 39,4 \%)$

Çalışmanın sonuçlarına göre, katılımcıların\% 60,2'si menopoz ile yaşlanma arasında bir ilişki olduğunu belirtmiştir. Bulgular, yaşlanmanın menopoz ve yaşlanma arasında bir ilişki olduğunu düşünen katılımcılar tarafından bir gerileme süreci olarak algılandığını ve bu gerilemenin menopoz semptomları ile ilişkili olduğunu göstermiştir.

Q10 ve Q11, menopozun yaşlılık algısı üzerindeki aracı rolünü belirlemeleri için soruldu. Q10 sorusu, bireyin çevredeki insanları yaşlanma ve yaşlıların deneyimlerini öz değerlendirme yoluyla yaşlanma algısı üzerindeki etkisi konusunda taklit edip etmediğini ölçer. Q11 sorusu, bir kadının çevresindeki insanları menopozla ilgili olarak taklit edip etmediğini ve menopoz sürecindeki kişilerin deneyimlerini taklit etmenin öz değerlendirme yoluyla menopoz algısı üzerindeki etkisini ölçer.

Tablo 5. Menopozun Yaşlılık Algısı Üzerindeki Aracılık Etkisi

\begin{tabular}{llllll}
\hline Q10 & $\mathbf{f}$ & $\mathbf{\%}$ & $\mathbf{Q 1 1}$ & $\mathbf{f}$ & $\mathbf{\%}$ \\
\hline Yes & 35 & 53 & Yes & 38 & 57,6 \\
No & 31 & 47 & No & 28 & 42,4 \\
\hline
\end{tabular}


Bulgulara göre, katılımcıların\% 53'ü çevrelerindeki insanların problemlerini yaşlılık ile, \% 57,6'sı ise kendi sorunlarını menopoz ile ilişkilendirmektedir. Kadınların\% 50'den fazlası çevrelerindeki deneyimlerden edinilen bilgiye önem vermektedir. Bu düşünce, içselleştirme yoluyla örneklenen olayın ortaya çıkma algısını artıııı. Bu bulgu, sosyal öğrenme yoluyla edinilen bilgilerin kadınlar için önemli olduğunu göstermektedir. Yaşlanma ve menopoz algısı edinilen bilgilerle karşılaştıııı ve içselleştirilir. Bilişsel süreçteki bu olay içselleştirmenin önemini ortaya koymaktadır.

\section{SONUÇ ve TARTIŞMA}

Yaşlanma algııının taklit yoluyla ortaya çıkması literatürde araştııımamıştır. Araştırmalar yaşlanmanın psikolojik, sosyal, ekonomik ve fiziksel etkilerine odaklanmaktadır (Lachman ve Agrigoroaei, 2010; Fiscella ve Franks, 1997; McTeer ve Curtis, 1990; Johnson vd., 2011). Araştırmalar, bireyin bilişsel işlevlerinin yaşlanma ile azaldığını ortaya koymaktadır (Ryan ve Burk, 1974; Ratcliff, Thapar ve McKoon, 2006; Hoyer ve Plude, 1980; Bayen ve Murnane, 1996; Rodrigue, Kennedy ve Raz, 2005). Algısal etkiler ve yaşlanma arasındaki ilişki, bilişsel işlev bozukluğunda yaşa bağlı gerileme ile ilişkilendirilmiştir (Thapar ve McKoon, 2006; Hoyer ve Plude, 1980; Bayen ve Murnane, 1996). Ancak, bu çalışmaların sonuçları, bireylerin bilişsel yaşlanma algısının nedenlerini açıklayamamaktadır.

Çalışmanın bulgularına göre menstrüasyon döneminde üzüntü, sinirlilik, anksiyete ve öfke gibi deneyimlenen ruh halleri yaşlanma algısı ile ilişkili değildir ve ilerleyen yaştan kaynaklanan menopoz bulguları yaşlanma algısına neden olmaktadır. Bulgular, menopozun yaşlanma algısını taklit edebileceğini ve menstrüasyon semptomlarının bu özelliğin ortaya çıkmasında etkili olduğunu göstermiştir. Literatürde çalışmanın bulgularına ilişkin benzer bir çalışma yoktur. Sonuçlar, kadınlarda yaşlanma algısının menopoz ve menstrüasyondan etkilendiğini açıkça göstermektedir.

Çalışmanın bulgularına göre, katılımcıların çoğunun kadın hastalığı geçirmediği tespit edilmiştir. Sağlığın yaşlanma üzerindeki etkileri düşünüldüğünde, yaşlanma algısının etkisi önemini ortaya koymaktadır. Bulgular, katılımcıların neredeyse yarısının menstrüasyon sırasında düzensizlik ve hormonal dengesizlik arasında bir ilişkiye olduğunu ortaya koymaktadır. Diğer taraftan, katılımcıların yaklaşık \% 40'ı menopozun hormonal dengesizlik ve adet döneminin uzun süreli gecikmesi ile ilişkili olduğunu belirtmiştir. Her iki bulgu birlikte değerlendirildiğinde, menopoz ve menstrüasyon arasında önemli bir ilişki olduğu tespit edilmiştir.

Kadınların yaşlanma algısına ilişkin bulgulara göre, katılımcıların yaklaşık \% 40'ı menstrüasyon ve yaşlılık arasında bir ilişki olduğunu ifade etmiştir. Diğer taraftan, katılımcıların \% 60'ından fazlası menopozun yaşlıık ile ilişkili olduğunu belirtmiştir. Tüm bu bulgular birlikte değerlendirildiğinde, menopozun yaşlılık algısı ile ilişkili olduğu görülmektedir. Bulgular, yaşlanmanın menopoz ve yaşlılık arasında bir ilişki olduğunu düşünen katılımcılar tarafından bir gerileme süreci olarak algılandığını ve bu gerilemeninn menopoz semptomları ile ilişkili olduğunu göstermiştir. 
Menopozun bilişsel öğrenme yoluyla kadınlarda yaşlanma algısını taklit edebildiği ortaya çıkarılmıştır. Taklit etme yeteneği, menstrüasyonun belirtilerinin yaşııık algısına etkisi ile belirlenmiştir. Katılımcılara yöneltilen sorular ve yanıtların sistematik analizinden sonra elde edilen sonuçlar birlikte değerlendirildiğinde, menopoz semptomları ile yaşıılık arasında anlamlı bir ilişki olduğu tespit edilmiştir. Son olarak, menopozun aracılık etkisi üzerindeki bulgulara göre, katııımcıların yaşlanma algısının yarııından fazlasının çevrelerinden ve menopoz sendromlarından elde edilen bilgilerden kaynaklandığı ortaya çıkmıştır. Bu aracılık etkisi önemli bir taklit etme yeteneğini ortaya koymaktadır. Bu sonuçlar, bireylerin sosyal öğrenme yoluyla elde ettikleri bilgileri bilişsel süreçte kodlayarak anladıklarını ve bilgileri yaşlılıkla ilişkilendirerek yaşlanma algısına sahip olduklarını göstermektedir. İçselleştirilmiş bilgi bireyin algısına göre şekillenir. Bu şekillendirme işleminin bir sonucu olarak, yaşlanma algısı oluşur. Bu sonuçlar yaşlanmanın patolojik ve bilişsel işlev bozukluğunun bir sonucu olduğu bulgularına önemli katkı sağlamaktadır.

\section{ÖNERILER}

Algının yaşlanma üzerindeki bu önemli etkileri literatürde multidisipliner olarak araştırımalıdır. Çalışmanın bulguları, sosyal öğrenmeden kaynaklanan algısal dönüşümün eğitim, teknoloji kabulü, örgütsel davranış ve başarıı yaşlanma ile ilgili literatüre önemli bir katkı sağlayacă̆ını ortaya koymaktadır. Kadınların yaşlanma süreciyle ilgili araştırmaların artırılması ve yaşlanma algııının başarılı yaşlanma ile birlikte değerlendirilmesi önerilmektedir. Çalışmanın bulgularının yaş algısı bağlamında menopozun taklit kabiliyetini ortaya koyması "gizli yaşlanma" kavramını gündeme getirmektedir.

Bu alandaki ilk çalışma Özsungur'un (2019) "Latent ageing" adlı çalışmasıdır. Bu çalışmada gizli yaşlanmanın fiziksel değişiklikler, hafifletici hastalıklar ve kronik ağrı ile ilişkili olduğu tespit edilmiştir. Gizli yaşlanma olarak adlandırılan yaşlılık türü, çevrelerinden sosyal öğrenme yoluyla elde edilen bilgi ve deneyimlerin karşılaştırılması sonucunda bireylerin yaşlılık sendromuna düştüğü durumdur. Menstrüasyon semptomlarını kullanan menopoz taklidi, gizli yaşlanma tipine benzemektedir. Bu nedenle, gelecekteki çalışmalarda bu yaşlılık türünün menopoz ve menstrüasyon bağlamında incelenmesi önerilmektedir. Ayrıca, klinik çalışmalar sonucunda elde edilecek patolojik bulgular literature katkıda bulunacaktır.

\section{ETiK BILDIRIMi}

Bu makalede dergi yazım kuralları, yayın ilkeleri, araştırma ve yayın etiği kuralları, dergi etiği kuralları takip edilmiştir. Makaleyle ilgili herhangi bir ihlalin sorumluluğu yazarlara aittir.

\section{KAYNAKÇA}

Abramovitz, M. (2017). Regulating the Lives of Women: Social Welfare Policy from Colonial Times to the Present. Routledge.

Bancroft, J. (1995). The Menstrual Cycle and the Well Being of Women. Social Science and Medicine, 41(6), 785791. 
Bayen, U. J. ve Murnane, K. (1996). Aging and the Use of Perceptual and Temporal Information in Source Memory Tasks. Psychology and Aging, 11(2), 293.

Byrne, M. (2001). Sampling for Qualitative Research. AORN journal, 73(2), 494-494.

Cameron, E., Ward, P., Mandville-Anstey, S. A. ve Coombs, A. (2019). The Female Aging Body: A Systematic Review of Female Perspectives on Aging, Health, and Body Image. Journal of Women \& Aging, 31(1), 317.

Clouston, S. A., Smith, D. M., Mukherjee, S., Zhang, Y., Hou, W., Link, B. G. ve Richards, M. (2019). Education and Cognitive Decline: An Integrative Analysis of Global Longitudinal Studies of Cognitive Aging. The Journals of Gerontology: Series B.

Condello, G., Capranica, L., Migliaccio, S., Forte, R., Di Baldassarre, A. ve Pesce, C. (2019). Energy Balance and Active Lifestyle: Potential Mediators of Health and Quality of Life Perception in Aging. Nutrients, 11(9), 2122.

Coveney, L., Jackson, M., Jeffreys, S., Kay, L. ve Mahony, P. (2019). The Sexuality Papers: Male Sexuality and the Social Control of Women. Routledge.

Crimmins, E. M., Shim, H., Zhang, Y. S. ve Kim, J. K. (2019). Differences Between Men and Women in Mortality and the Health Dimensions of the Morbidity Process. Clinical chemistry, 65(1), 135-145.

Dye, L., Warner, P. ve Bancroft, J. (1995). Food Craving During the Menstrual Cycle and its Relationship to Stress, Happiness of Relationship and Depression; a Preliminary Enquiry. Journal of Affective Disorders, 34(3), 157-164.

Fiscella, K. ve Franks, P. (1997). Does Psychological Distress Contribute to Racial and Socioeconomic Disparities in Mortality? Social Science \& Medicine, 45(12), 1805-1809.

Franceschi, C., Garagnani, P., Gensous, N., Bacalini, M. G., Conte, M. ve Salvioli, S. (2019). Accelerated Bio-Cognitive Aging in Down Syndrome: State of the Art and Possible Deceleration Strategies. Aging Cell, 18(3), e12903.

Gall MD, Barg, W. R. ve Gall, J. P. (1996). Educational Research: an Introduction 6th (edn.). New York: Longman.

Gambacciani, M., Biglia, N., Cagnacci, A., DI Carlo, C., Caruso, S., Cicinelli, E. ve Lanzone, A. (2018). Menopause and Hormone Replacement Therapy. The 2017 Recommendations of the Italian Menopause Society. Minerva Ginecol, 70(1), 27-34.

Gerring J. (2004) What is a Case Study and What is it Good for?, American Political Science Review 98 (2), 341 354.

Golub, S. (2017). Lifting the Curse of Menstruation: A Feminist Appraisal of the Influence of Menstruation on Women's Lives. Routledge.

Goodwin, B. J., Interligi, C. J., Kasardo, A. E., McHugh, M. C. ve Poet, A. D. (2019). Who is the Woman in the Psychology of Women? Addressing Diversity and Intersectionality. In J. A. Mena ve K. Quina (Eds.), Integrating Multiculturalism and Intersectionality into the Psychology Curriculum: Strategies for Instructors (p. 51-62). American Psychological Association. https://doi.org/10.1037/0000137-005

Greer, G. (2018). The Change: Women, Ageing and the Menopause. Bloomsbury Publishing. 
Gurera, J. W. ve Isaacowitz, D. M. (2019). Emotion Regulation and Emotion Perception in Aging: A Perspective on Age-Related Differences and Similarities. Progress in Brain Research, 247, 329-351.

Haines, S. J., Shelton, J. T., Henry, J. D., Terrett, G., Vorwerk, T. ve Rendell, P. G. (2019). Prospective Memory and Cognitive Aging. In Oxford Research Encyclopedia of Psychology.

Harlow, B. L., Wise, L. A., Otto, M. W., Soares, C. N. ve Cohen, L. S. (2003). Depression and its Influence on Reproductive Endocrine and Menstrual Cycle Markers Associated with Perimenopause: the Harvard Study of Moods and Cycles. Archives of General Psychiatry, 60(1), 29-36.

Hooker, K., Mejía, S. T., Phibbs, S., Tan, E. J. ve Stevens, J. (2019). Effects of Age Discrimination on SelfPerceptions of Aging and Cancer Risk Behaviors. The Gerontologist, 59 (Supplement_1), S28-S37.

Hosseini, A. S. S. (2018). Unpreparedness, Impurity and paradoxical Feeling: Menstruation Narratives of Iranian Women. International Journal of Adolescent Medicine and Health.

Hoyer, W. J. ve Plude, D. J. (1980). Attentional and Perceptual Processes in the Study of Cognitive Aging. In L. W. Poon (Ed.), Aging in the 1980s: Psychological Issues (p. 227-238). American Psychological Association. https://doi.org/10.1037/10050-016

Ismail, K., Pedro, A. ve Andipatin, M. (2016). Exploring a Sample of University Students' Perceptions of Menstruation. Journal of Psychology in Africa, 26(4), 394-396.

Jenraumjit, R., Chinwong, S., Chinwong, D., Kanjanarach, T., Kshetradat, T., Wongpakaran, T. ve Wongpakaran, N. (2020). Anticholinergics and Benzodiazepines on Cognitive Impairment Among Elderly with Alzheimer's Disease: A 1 Year Follow-Up Study. BMC Research Notes, 13(1), 1-6.

Johnstone, R. A. ve Cant, M. A. (2019). Evolution of Menopause. Current Biology, 29(4), R112-R115.

Johnson, W., Corley, J., Starr, J. M. ve Deary, I. J. (2011). Psychological and Physical Health at Age 70 in the Lothian Birth Cohort 1936: Links with Early Life IQ, SES, And Current Cognitive Function and Neighborhood Environment. Health Psychology, 30(1), 1.

Karim, R., Koc, M., Rettberg, J. R., Hodis, H. N., Henderson, V. W., John, J. A. S. ve Mack, W. J. (2019). Apolipoprotein E4 Genotype in Combination with Poor Metabolic Profile is Associated with Reduced Cognitive Performance in Healthy Postmenopausal Women: Implications for Late Onset Alzheimer's Disease. Menopause, 26(1), 7-15.

Karlsson, P., Thorvaldsson, V. ve Johansson, B. (2019). Birth Cohort Differences in Cognitive Aging: Secular Trends Over 30 Years in Three Swedish Samples. In IAGG-ER 2019.

Kittell, L. A., Mansfield, P. K. ve Voda, A. M. (1998). Keeping up Appearances: The Basic Social Process of the Menopausal Transition. Qualitative Health Research, 8(5), 618-633.

Koerber, A. ve McMichael, L. (2008). Qualitative Sampling Methods: A Primer for Technical Communicators. Journal of Business and Technical Communication, 22(4), 454-473.

Koeske, R. D. (2017). Lifting the Curse of Menstruation: Toward a Feminist Perspective on the Menstrual Cycle. in Lifting the Curse of Menstruation (pp. 1-16). Routledge.

Koff, E., Rierdan, J. ve Stubbs, M. L. (1990). Conceptions and Misconceptions of the Menstrual Cycle. Women \& Health, 16(3-4), 119-136. 
Komanduri, M., Gondalia, S., Scholey, A. ve Stough, C. (2019). The Microbiome and Cognitive Aging: a Review of Mechanisms. Psychopharmacology, 1-13.

Lachman, M. E. ve Agrigoroaei, S. (2010). Promoting Functional Health in Midlife and Old Age: Long-Term Protective Effects of Control Beliefs, Social Support, and Physical Exercise. PloS one, 5(10), e13297.

Lamar, M., Boots, E. A., Arfanakis, K., Barnes, L. L. ve Schneider, J. A. (2020). Brain Structural Alterations Common to Cardiovascular Disease Risk Factors and Alzheimer's Dementia. Vascular Disease, Alzheimer's Disease, and Mild Cognitive Impairment: Advancing an Integrated Approach, 241.

Levine, M. E., Lu, A. T., Chen, B. H., Hernandez, D. G., Singleton, A. B., Ferrucci, L. ve Kusters, C. D. (2016). Menopause Accelerates Biological Aging. Proceedings of the National Academy of Sciences, 113(33), 9327-9332.

Levy, B. R. ve Myers, L. M. (2004). Preventive Health Behaviors Influenced by Self-Perceptions of Aging. Preventive Medicine, 39(3), 625-629.

Levy, B. R., Slade, M. D., Kunkel, S. R. ve Kasl, S. V. (2002). Longevity Increased by Positive Self-Perceptions of Aging. Journal of Personality and Social Psychology, 83(2), 261.

Levy, B. R., Slade, M. D. ve Kasl, S. V. (2002). Longitudinal Benefit of Positive Self-Perceptions of Aging on Functional Health. The Journals of Gerontology Series B: Psychological Sciences and Social Sciences, 57(5), P409-P417.

Manson, J. E. ve Kaunitz, A. M. (2016). Menopause Management-Getting Clinical Care Back on Track. New England Journal of Medicine, 374(9), 803-806.

Marshall, M. N. (1996). Sampling for Qualitative Research. Family Practice, 13(6), 522-526.

Martin, E. (1988). Medical Metaphors of Women's Bodies: Menstruation and Menopause. International Journal of Health Services, 18(2), 237-254.

Marván, M. L. ve Chrisler, J. C. (2018). Menarcheal Timing, Memories of Menarche, and Later Attitudes Toward Menstruation. Cogent Psychology, 5(1), 1525840.

Maxwell J.A. (1996). Applied Social Research Methods Series, Qualitative Research Design: an Interactive Approach. Thousand Oaks, CA, US: Sage Publications 41.

McGannon, K. R., Schinke, R. J., Ge, Y. ve Blodgett, A. T. (2019). Negotiating Gender and Sexuality: a Qualitative Study of Elite Women Boxer Intersecting Identities and Sport Psychology Implications. Journal of Applied Sport Psychology, 31(2), 168-186.

McTeer, W. ve Curtis, J. E. (1990). Physical Activity and Psychological Well-Being: Testing Alternative Sociological Interpretations. Sociology of Sport Journal, 7(4), 329-346.

Meriwether, M. L. (2018). A Social History of Women and Gender in the Modern Middle East. Routledge.

Metcalf, M. G., Livesey, J. H., Wells, J. E., Braiden, V., Hudson, S. M. ve Bamber, L. (1991). Premenstrual Syndrome in Hysterectomized Women: Mood and Physical Symptom Cyclicity. Journal of Psychosomatic Research, 35(4-5), 555-567. 
Meyvaci, S. S., Bamaç, B., Duran, B., Çolak, T. ve Memişoğlu, K. (2020). Effect of Surgical and Natural Menopause on Proximal Femur Morphometry in Obese Women. Annals of Anatomy-Anatomischer Anzeiger, 227, 151416.

Michael, J., Iqbal, Q., Haider, S., Khalid, A., Haque, N., Ishaq, R. ve Bashaar, M. (2020). Knowledge and Practice of Adolescent Females About Menstruation and Menstruation Hygiene Visiting a Public Healthcare Institute of Quetta, Pakistan. BMC Women's Health, 20(1), 1-8.

Mihas, P. 2019. Qualitative Data Analysis. In Oxford Research Encyclopedia of Education.

Mobarak, H., Heidarpour, M., Lolicato, F., Nouri, M., Rahbarghazi, R. ve Mahdipour, M. (2019). Physiological Impact of Extracellular Vesicles on Female Reproductive System; Highlights to Possible Restorative Effects on Female Age-Related Fertility. BioFactors.

Moeller, S. J., Goodwin, R. D., Sullivan, R. M. ve Verdejo-Garcia, A. (2020). Drug Use and Self-Awareness of Treatment Need: an Exemplar of How Population-Based Survey Studies Can Address Questions Relevant to the Neuroscience of Insight. In Cognition and Addiction (pp. 351-364). Academic Press.

Morse, C. A. ve Dennerstein, L. (1988). Cognitive therapy for Premenstrual Syndrome. In Functional Disorders of the Menstrual Cycle (pp. 177-190). John Wiley, Chichester.

Motro, D., Gabriel, A. S. ve Ellis, A. P. (2019). Examining the Effects of Menstruation on Women's Helping Behaviour in the Workplace. Journal of Occupational and Organizational Psychology.

Muhleisen, A. L. ve Herbst-Kralovetz, M. M. (2016). Menopause and the Vaginal Microbiome. Maturitas, 91, 4250.

Nelson, D. B., Sammel, M. D., Freeman, E. W., Lin, H., Gracia, C. R. ve Schmitz, K. H. (2008). Effect of Physical Activity on Menopausal Symptoms Among Urban Women. Medicine \& Science in Sports \& Exercise, 40(1), 50-58.

Parlee, M. B. (1976). Social Factors in the Psychology of Menstruation, Birth, and Menopause. Primary Care, 3(3), 477-490.

Porter, M., Penney, G. C., Russell, D., Russell, E. ve Templeton, A. (1996). A Population Based Survey of Women's Experience of the Menopause. BJOG: An International Journal of Obstetrics \& Gynaecology, 103(10), 1025-1028.

Özsungur, F. (2019). Latent Aging. Biomedical Journal of Scientific \& Technical Research (BJSTR). 20(4)-2019. BJSTR. MS.ID.003497.

Parish, A., Kim, J., Lewallen, K. M., Miller, S., Myers, J., Panepinto, R. ve Maxwell, C. A. (2019). Knowledge and Perceptions About Aging and Frailty: An Integrative Review of the Literature. Geriatric Nursing, 40(1), 13-24.

Petkus, A. J., Filoteo, J. V., Schiehser, D. M., Gomez, M. E., Hui, J. S., Jarrahi, B. ve Petzinger, G. M. (2020). Mild Cognitive Impairment, Psychiatric Symptoms, and Executive Functioning in Patients with Parkinson's Disease. International Journal of Geriatric Psychiatry. 
Prior, J. C. (2020). Postpartum Lactational Amenorrhea and Recovery of Reproductive Function and Normal Ovulatory Menstruation. In Maternal-Fetal and Neonatal Endocrinology (pp. 207-214). Academic Press.

Ratcliff, R., Thapar, A. ve McKoon, G. (2006). Aging, Practice, and Perceptual Tasks: a Diffusion Model Analysis. Psychology and aging, 21(2), 353.

Ray, S. ve Agarwal, P. (2020). Depression and Anxiety in Parkinson Disease. Clinics in Geriatric Medicine, 36(1), 93-104.

Reiber, C. (2010). Female Gamete Competition: a New Evolutionary Perspective on Menopause. Journal of Social, Evolutionary, and Cultural Psychology, 4(4), 215-240. https://doi.org/10.1037/h0099287

Reicher, L., Yogev, Y. ve Maslovitz, S. (2020). 730: Should Women Wait for the First Menstrual Period Following Spontaneous Miscarriage Before Becoming Pregnant Again?. American Journal of Obstetrics \& Gynecology, 222(1), S462.

Reid, R. L., Black, D., Derzko, C. ve Portman, D. (2020). Ospemifene: A Novel Oral Therapy for Vulvovaginal Atrophy of Menopause. Journal of Obstetrics and Gynaecology Canada.

Richardson, N. (2020). Your Period Handbook: Natural Solutions for Stress Free Menstruation. Karnac Books.

Riley, S., Brooks, J., Goodman, S., Cahill, S., Branney, P., Treharne, G., and Sullivan, C. 2019. Celebrations Amongst Challenges: Considering the Past, Present and Future of the Qualitative Methods in Psychology (QMiP) section of the British Psychological Society.

Roberts, J. G. (2019). Effects of Cognitive Aging on AMPA and NMDA Receptor Expression in CA3 and CA1 Pyramidal Neurons (Doctoral dissertation, Rush University).

Rodrigue, K. M., Kennedy, K. M. ve Raz, N. (2005). Aging and Longitudinal Change in Perceptual-Motor Skill Acquisition in Healthy Adults. The Journals of Gerontology Series B: Psychological Sciences and Social Sciences, 60(4), P174-P181.

Russell, J. K., Jones, C. K. ve Newhouse, P. A. (2019). The Role of Estrogen in Brain and Cognitive Aging. Neurotherapeutics, 1-17.

Ryan, W. J. ve Burk, K. W. (1974). Perceptual and Acoustic Correlates of Aging in the Speech of Males. Journal of communication disorders, 7(2), 181-192.

Salthouse, T. A. (2019). Trajectories of Normal Cognitive Aging. Psychology and Aging, 34(1), 17.

Sanders, D., Warner, P., Backstrom, T. ve Bancroft, J. (1983). Mood, sexuality, Hormones and the Menstrual Cycle. I. Changes in Mood and Physical State: Description of Subjects and Method. Psychosomatic Medicine, 45(6), 487-501.

Sexton, C. E., Sykara, K., Karageorgiou, E., Zitser, J., Rosa, T., Yaffe, K. ve Leng, Y. (2019). Connections Between Insomnia and Cognitive Aging. Neuroscience Bulletin, 1-8.

Skultans, V. (1970). The Symbolic Significance of Menstruation and the Menopause. Man, 5(4), 639-651.

Smail, L., Jassim, G. ve Shakil, A. (2020). Menopause-Specific Quality of Life among Emirati Women. International Journal of Environmental Research and Public Health, 17(1), 40. 
Smith, J. L. ve Bryant, F. B. (2019). Enhancing Positive Perceptions of Aging by Savoring Life Lessons. Aging \& Mental Health, 23(6), 762-770.

Sobhani, Z., Karimi, A., MoeinVaziri, N., Zare, A. ve Amini, M. (2019). A Pregnant Lady Undergoing Bariatric Surgery. Obesity surgery, 1-3.

Spiers, J., and Riley, R. 2019. Analysing one Dataset with Two Qualitative Methods: The Distress of General Practitioners, a Thematic and Interpretative Phenomenological Analysis. Qualitative Research in Psychology, 16(2), 276-290.

Spradley J. P. (1980). Participant Observation. Orlando FL: Harcourt Inc. Spreitzer GM Psychological Empowerment in the Workplace: Dimensions, Measurement, and Validation. Academy of Management Journal 38(5), 1442-1465.

Srivarathan, A., Jensen, A. N. ve Kristiansen, M. (2019). Community-Based Interventions to Enhance Healthy Aging in Disadvantaged Areas: Perceptions of Older Adults and Health Care Professionals. BMC Health Services Research, 19(1), 7.

Taskin, O., Gökdeniz, R., Muderrisoglu, H., Korkmaz, M. E., Uryan, I., Atmaca, R. ve Kafkasli, A. (1998). The Effects of Hormone Replacement Therapy on Echocardiographic Basic Cardiac Functions in Postmenopausal Women. Human Reproduction (Oxford, England), 13(9), 2399-2401.

Tenner, A. J. (2020). Complement-Mediated Events in Alzheimer's Disease: Mechanisms and Potential Therapeutic Targets. The Journal of Immunology, 204(2), 306-315.

Tilly, L. A. ve Scott, J. W. (2016). Women, Work and Family. Routledge.

Treloar, A. E. (1981). Menstrual Cyclicity and the Pre-Menopause. Maturitas, 3(3-4), 249-264.

Tucker-Drob, E. M. (2019). Cognitive Aging and Dementia: A Life-Span Perspective. Annual Review of Developmental Psychology, 1, 177-196.

Watson, L. B. (2019). Gender Identity and Expression in LGBTQ+ Communities: Implications for the Practice of Psychology. Psychology of Women Quarterly, 0361684319846498.

Webb, C. E., Rodrigue, K. M., Hoagey, D. A., Foster, C. M. ve Kennedy, K. M. (2019). Contributions of White Matter Connectivity and BOLD Modulation to Cognitive Aging: A lifespan Structure-Function Association Study. Biorxiv, 620443.

Yu, J., Collinson, S. L., Liew, T. M., Ng, T. P., Mahendran, R., Kua, E. H. ve Feng, L. (2019). Super-Cognition in Aging: Cognitive Profiles and Associated Lifestyle Factors. Applied Neuropsychology: Adult, 1-7.

Zimmerman, E. ve Parlee, M. B. (1973). Behavioral Changes Associated with the Menstrual Cycle: An Experimental Investigation 1. Journal of Applied Social Psychology, 3(4), 335-344. 
Ek 1. Çalışma Soruları

\section{Sira Sorular}

Q1.Daha önce doktor tarafından teşhis edilmiş bir kadın rahatsızlığı geçirdiniz mi?

Q2.Rahatsızlığınız neydi?

Q3. Menstürasyon döneminde düzensizlik yaşadığınızda kendinizde ne gibi bir rahatsızlık olduğunu düşünürsünüz?

Q4. Adet döneminiz kısa süreliğine geciktiğinde ya da erken adet olduğunuzda sizce bu durum ne ile ilgili olabilir?

Q5. Adet döneminiz uzun süreliğine geciktiğinde sizce bu durum ne ile ilgili olabilir?

Q6. Menopoz ile ilgili ne düşünüyorsunuz? Sizce hangi etkenler menopoza sebep olur?

Q7. Sizce aşağıdaki menstürasyon sorunlarından hangisi menopozla ilgilidir?

Q8. Menstürasyonun yaşlılıkla bir ilişkisi olduğunu düşünüyor musunuz? Cevabınız evet ise hangi durumlarda? Yukarıdaki soruya cevabınız evet ise Nasıl bir ilişkisi vardır?

Q9. Menopozun yaşlılıkla bir ilişkisi olduğunu düşünüyor musunuz?

Yukarıdaki soruya cevabınız evet ise Nasıl bir ilişkisi vardır?

Q10.Etrafınızdaki yaşlı insanların yaşadıkları sorunları kendiniz yaşadığınızda yaşlandığınızı hisseder misiniz?

Q11. Menopoza giren bir kadının yaşadıklarını siz de yaşadığınızda menopoza gireceğinizi düşünür müsünüz? 